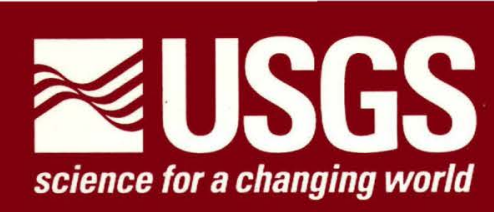

\author{
In cooperation with the \\ Maryland Department of Natural Resources \\ Chesapeake and Coastal Watershed Service
}

\title{
Nutrient and Sediment Concentrations, Trends, and Loads From Five Subwatersheds in the Patuxent River Basin, Maryland, 1986-96
}

Water-Resources Investigations Report 98-4221 


\title{
Nutrient and Sediment Concentrations, Trends, and Loads From Five Subwatersheds in the Patuxent River Basin, Maryland, 1986-96
}

\author{
by Joy S. Lizárraga
}

Water-Resources Investigations Report 98-4221

\author{
In cooperation with the \\ Maryland Department of Natural Resources \\ Chesapeake and Coastal Watershed Service
}


U.S. Department of the Interior

BRUCE BABBITT, Secretary

U.S. Geological Survey

Charles G. Groat, Director

The use of trade, product, or firm names in this report is for descriptive purposes only and does not imply endorsement by the U.S. Geological Survey.

For additional information contact:

District Chief

U.S. Geological Survey, WRD

8987 Yellow Brick Road

Baltimore, MD 21237

Copies of this report can be purchased from:

U.S. Geological Survey

Branch of Information Services

Box 25286

Denver, CO 80225-0286 


\section{Contents}

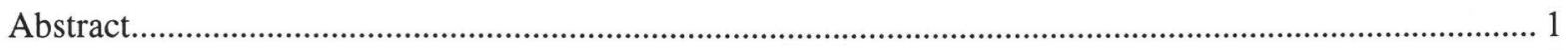

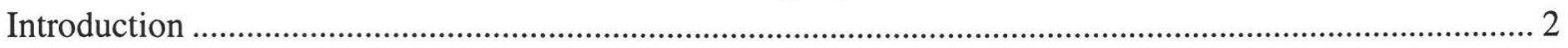

Purpose and scope

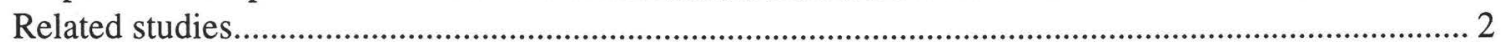

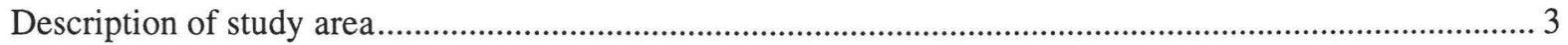

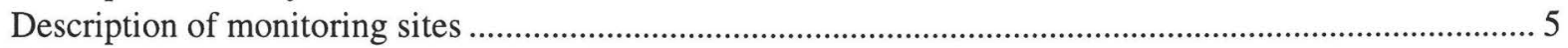

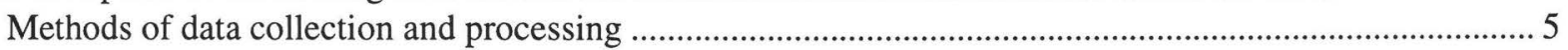

U.S. Geological Survey water-quality and streamflow data collection ............................................ 5

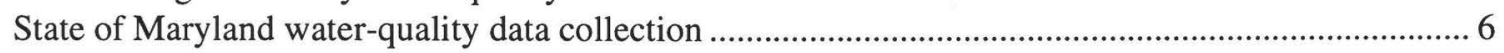

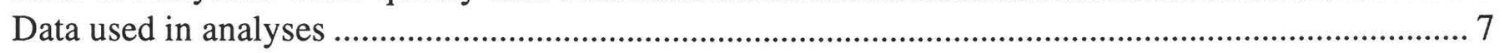

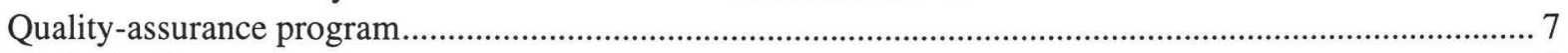

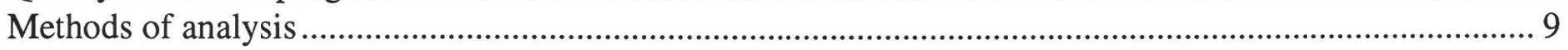

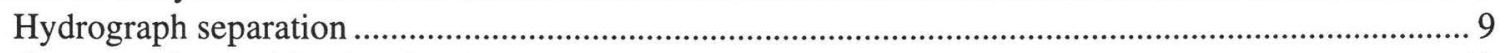

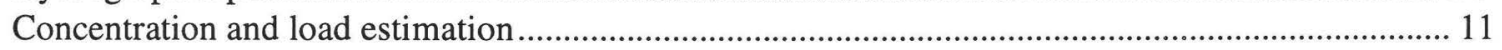

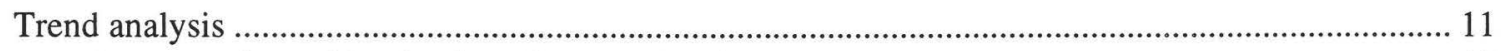

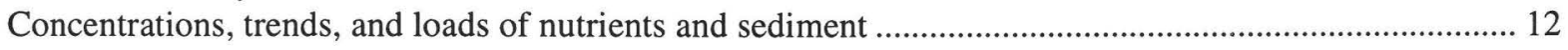

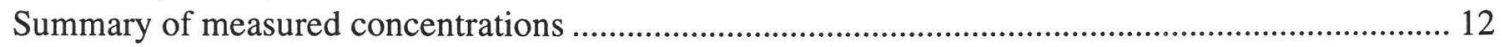

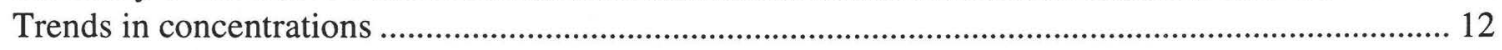

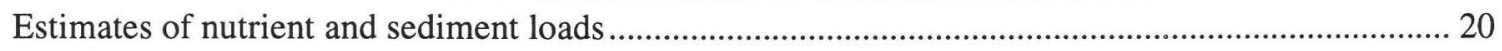

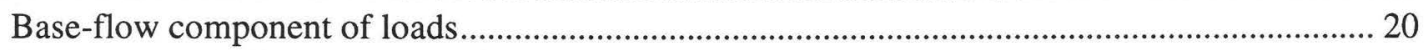

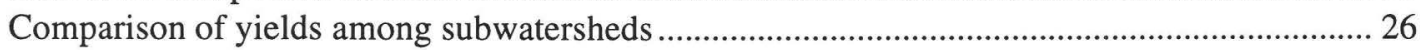

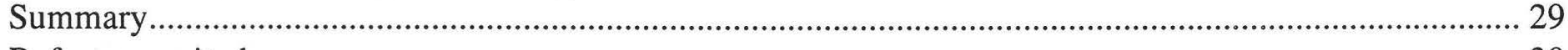

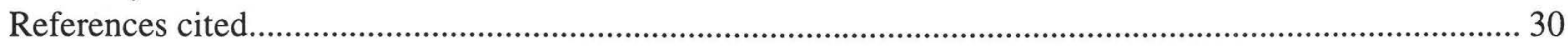

\section{Figures}

1. Map of study area showing the location of monitoring sites and subwatersheds in the Patuxent River Basin ................................................................................... 4

2. Boxplots showing nutrient and sediment concentrations in quality-control blanks and stream samples collected by the U.S. Geological Survey, Patuxent River Basin, 1986-96 .......................................................... 8

3. Plots showing nutrient and sediment concentrations in duplicate samples collected by the U.S. Geological Survey and the State of Maryland, Patuxent River Basin, 1986-96.

4. Boxplots showing measured concentrations of nutrients and sediment in base-flow and storm-runoff samples collected from subwatersheds in the Patuxent River Basin, 1986-96 at:

(A) Patuxent River near Unity (site 1)...

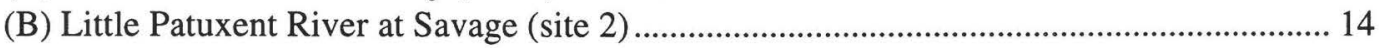

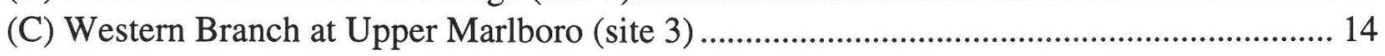

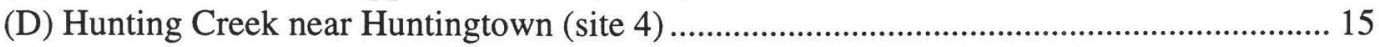

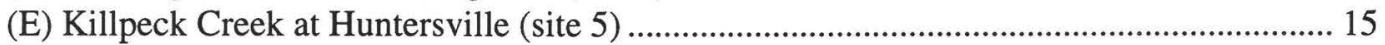




\section{Figures--Continued}

5. Plots showing trends in flow-adjusted concentrations of total nitrogen, nitrite plus nitrate, total phosphorus, total suspended solids, and suspended sediment at

five monitoring sites in the Patuxent River Basin, 1986-96

6. Time-series plot showing nitrogen concentrations and mean-daily discharge

at the Little Patuxent River at Savage, 1986-96

7. Time-series plot showing annual yields of nutrients, suspended solids, suspended sediment, and water from five subwatersheds in the Patuxent River Basin, 1986-96

8. Boxplots showing distribution of annual yields of nutrients, suspended solids, suspended sediment, and water from five subwatersheds in the Patuxent River Basin, 1986-96

\section{Tables}

1. Drainage area, physiographic province, and land use/land cover in five subwatersheds in the Patuxent River Basin

2. Percentage of storms sampled at five monitoring sites in the

Patuxent River Basin, 1986-96

3. Regression-model beta coefficient estimates and diagnostics, 1986-96

4. Estimated loads and yield of total nitrogen at five monitoring sites

in the Patuxent River Basin, 1986-96

5. Estimated loads and yield of nitrite plus nitrate at five monitoring sites

in the Patuxent River Basin, 1986-96

6. Estimated loads and yield of total phosphorus at five monitoring sites in the Patuxent River Basin, 1986-96

7. Estimated loads and yield of total suspended solids at five monitoring sites in the Patuxent River Basin, 1986-96

8. Estimated loads and yield of suspended sediment at five monitoring sites in the Patuxent River Basin, 1986-96 


\section{Conversion Factors and Abbreviations}

\begin{tabular}{rll}
\hline Multiply & By & To obtain \\
& & \\
mile $(\mathrm{mi})$ & 1.609 & kilometer \\
square mile $\left(\mathrm{mi}^{2}\right)$ & 2.590 & square kilometer \\
kilogram \\
cubic meter per second
\end{tabular}

Chemical concentration in water is expressed in milligrams per liter $(\mathrm{mg} / \mathrm{L})$.

Water Year: A water year is the 12-month period from October 1 through September 30. The water year is designated by the calendar year in which it ends, and includes 9 of the 12 months. Thus, the year ending September 30,1993 , is called the "1993 water year." 



\title{
Nutrient and Sediment Concentrations, Trends, and Loads From Five Subwatersheds in the Patuxent River Basin, Maryland,1986-96
}

\author{
By Joy S. Lizárraga
}

\section{Abstract}

Five representative subwatersheds in the Patuxent River Basin were intensively sampled from 1986-96 to assess progress toward Chesapeake Bay Program nutrientand sediment-reduction goals for the year 2000. These subwatersheds represent approximately 25 percent of the surface area of the basin. On the basis of data collected from 1993-96, when all five sites were in operation, the estimated average-annual load of total nitrogen from these subwatersheds was 1.4 million pounds, and the estimated average-annual load of nitrite plus nitrate was 0.74 million pounds, slightly more than half of the load of total nitrogen. The estimated average-annual load of total phosphorus was 0.23 million pounds. The estimated average-annual loads of suspended solids and suspended sediment were 260 and 275 million pounds, respectively. These amounts are equivalent to 40 percent of the 3.5-million-pound goal for combined point- and nonpoint-source nitrogen load and 70 percent of the 0.33-million-pound goal for point- and nonpoint-source phosphorus load for the Patuxent River Basin.

When discharge and seasonality were accounted for in a statistical regression, concentrations of total phosphorus decreased from 1986-96 at all the sites in the basin. Estimated concentrations of sediment did not decrease with time at all sites, which indicates that concentrations of total phosphorus may have decreased independently of sediment management. Estimated concentrations of total nitrogen and nitrite plus nitrate increased at the Little Patuxent River and Killpeck Creek sites, and decreased at the Hunting Creek site.

Differences in the yield of nutrients and sediment among five subwatersheds appear to be influenced by a combination of the hydrologic and water-chemistry characteristics related to physiographic province and land use. Further evaluation is needed to identify reasons for these differences with more certainty. Nitrite-plus-nitrate yields were consistently lower from the three southern Coastal Plain subwatersheds than from the two northern Piedmont subwatersheds. Annual yields of total phosphorus, total suspended solids, and suspended sediment decreased and increased in concert with decreasing and increasing annual water yields from each subwatershed, and the highest and most variable yields of these water-quality constituents were from the most urbanized subwatersheds. 


\section{Introduction}

Water-quality degradation associated with elevated nutrient and suspended-sediment loads has been well documented in the Patuxent River and estuary (Mihursky and Boynton, 1978; Heinle and others, 1980; O'Conner and others, 1981; U.S. Environmental Protection Agency, 1990). To address this degradation, the State of Maryland developed and initiated the Patuxent Nutrient Control Strategy with significant input from local governments, utility agencies, and other user groups (Office of Environmental Programs, 1983). The Patuxent Nutrient Control Strategy identified specific nitrogen- and phosphorusreduction goals for the Patuxent River Basin to improve water quality in the river and estuary. Nonpoint-source nitrogen loads were to be reduced by 2,000 pounds per day $(0.73$ million pounds per year, or lb/yr) from 1981 loads. It was expected that nonpoint-source phosphorus loads would be reduced through control of sediment runoff to be achieved under agricultural and stormwater-management programs.

Superseding the Patuxent Nutrient Control Strategy, the State of Maryland has committed to a 40 -percent reduction of controllable nutrient and phosphorus loads (on the basis of 1985 loads) from Maryland to the Chesapeake Bay by the year 2000 (Galloway, 1993). The controllable load includes both the estimated point-source load and a large percentage of the load from nonpoint sources. It does not include the loads of nitrogen and phosphorus from forested areas, which are considered non-controllable. In the Patuxent River Basin, 64 percent of the nitrogen load and 90 percent of the phosphorus load are considered to be controllable (U.S. Environmental Protection Agency, 1992). In the Patuxent River Basin, the 40-percent reduction has been translated into annual maximum allowable loads of nitrogen (3.5 million lbs/year) and phosphorus ( 0.33 million lbs/year) from the Patuxent River Basin to the Bay (Patuxent River Commission, 1996).

In the early 1980 's, there was considerable uncertainty about the amount of nutrient and sediment load in the Patuxent River Basin. Therefore, the U.S. Geological Survey (USGS), in cooperation with the State of Maryland, initiated a study of the basin in September 1985 to better estimate loading, evaluate the effectiveness of nutrient-management strategies, and further understand the processes that contribute to nonpoint-source nutrient and sediment loading to the Patuxent estuary and the Chesapeake Bay from the Patuxent River Basin.

\section{Purpose and Scope}

This report summarizes the water-quality data collected in the Patuxent watershed by the USGS and State of Maryland during water years 1986-96. The purposes of the report are to: (1) summarize the available nutrient and sediment data, (2) estimate concentrations, trends, loads, and yields of five constituents in the water-quality data base, and (3) compare concentrations, trends, loads, and yields among the different sites in the Patuxent River Basin and to the 40-percent nutrient-reduction strategies. Concentrations, trends, and loads were determined for five waterquality constituents using a seven-parameter statistical regression analysis model.

\section{Related Studies}

Loads and trends of nutrients and sediment from nontidal areas of the Chesapeake Bay are periodically estimated using data collected and/or compiled as part of two other USGS programs, the Chesapeake Bay River-Input Monitoring Program and the Nontidal Synthesis Program. For the Chesapeake Bay River-Input Monitoring Program, the seven-parameter statistical regression analysis model (Bradu and Mundlak, 1970; Cohn and others, 1989; Cohn and others, 1992) is used to estimate annual nutrient and suspendedsediment loads to the Chesapeake Bay from its major tributaries, including the Patuxent River (Darrell and others, in press). The site used to assess loads and trends in nutrient and sediment concentrations to Chesapeake Bay from the nontidal part of the Patuxent River Basin is located at the USGS monitoring station on the Patuxent River at Bowie, Md. The monitoring data at the Bowie site is influenced by point-source discharges upstream.

Langland and others (1998) used selected USGS and State data collected in the Patuxent River Basin and described in this report to estimate nutrient and sediment trends as part of the Chesapeake Bay Nontidal Synthesis Program. The seven-parameter statistical regression analysis model was used, but separate calibrations were performed for data collected by the USGS and by the State of Maryland. Trends tended to be different in magnitude, but similar in direction to 
the trends estimated in this report. This is most likely due to slightly different calibration periods and data sets.

The 1986-90 monitoring data from this study were previously analyzed, and nutrient and sediment loads were estimated by Preston and Summers (1996). Two statistical methods for load estimation were compared, one of which was the seven-parameter model. On the basis of the comparison and the extensive coverage of highdischarge events since that comparison, the sevenparameter model was selected for this analysis.

Low-flow synoptic sampling was performed in the Patuxent River Basin during the summers of 1993-95 to provide additional information about the causes of spatial water-quality variations (Preston, 1996). One significant finding was that concentrations of nitrite plus nitrate are higher in the Piedmont Physiographic Province than in the Coastal Plain Physiographic Province during lowflow conditions, and that this was largely due to variations in the ground water discharging to the streams. Ground-water quality is affected by a combination of factors related to physiography and land use, including the length of the groundwater-flow paths, the geochemical reactivity of the sediments through which the water passes, and anthropogenic sources of nutrients on the surface.

Local conditions and management practices may override the generalization [based on the work by Preston (1996)] that concentrations of nitrite plus nitrate during low-flow conditions are higher in the Piedmont than in the Coastal Plain, as was the case in a two-site study by McFarland (1996). But the results of this study corroborate the findings of the low-flow synoptics of 1993-95 for concentrations of nitrite plus nitrate during low-flow conditions.

\section{Description of Study Area}

The Patuxent River Basin is entirely within the State of Maryland and traverses the corridor between two major metropolitan areas, Baltimore, Md., and Washington, D.C. (fig. 1). The basin covers an area of approximately
$930 \mathrm{mi}^{2}$ and rarely exceeds a width of $15 \mathrm{mi}$. The main river channel is $110 \mathrm{mi}$ long.

Because of the proximity of the Patuxent watershed to Baltimore, Md., and Washington, D.C., its population increased during the course of this study. Between 1970 and 1990, population in the basin increased almost 90 percent, from 261,907 to 490,915 , and population is expected to increase to 757,000 by the year 2020 (Patuxent River Commission, 1996).

The watershed spans part of the Fall Line ${ }^{1}$ and two physiographic provinces, the Piedmont, which is characterized by rolling hills and rugged terrain, and the Coastal Plain, which is characterized by a relatively shallow gradient and slow, meandering streams. The way in which nutrients and sediment originate and are transported in the Patuxent River Basin is related to the geologic, hydrologic, and geomorphic characteristics of the Fall Line and each physiographic province.

The Piedmont Province is comprised of siliciclastic and metamorphic crystalline rock types. The Coastal Plain Province is comprised of multiple layers of unconsolidated sediment.

The rock type and sediments affect the movement of water and nutrients into and through the ground-water-flow system. The characteristics of physiographic provinces are related to the land use/land cover as well. This is due to a number of hydrogeologic factors, including the slope, soil drainage, and depth to water. In the Piedmont Province in the northern part of the basin, land use is predominantly agricultural and becomes progressively more urban near the Baltimore-Washington, D.C., corridor in the Fall Line region. Near the Fall Line, the percentage of urban and residential land use is higher, although large areas of the land are still forested. In the Coastal Plain Province in the southern part of the basin, the fraction of total land dedicated to urban and residential land use is lower, and forest is the predominant land cover.

\footnotetext{
${ }^{1}$ The "Fall Line" refers to a distinct change in slope generally along a line trending southwest to northeast through the Chesapeake Bay Basin. This line approximately coincides with the edge of the overlap of the unconsolidated sediment of the Coastal Plain Physiographic Province on the harder crystalline rocks of the Piedmont Physiographic Province.
} 


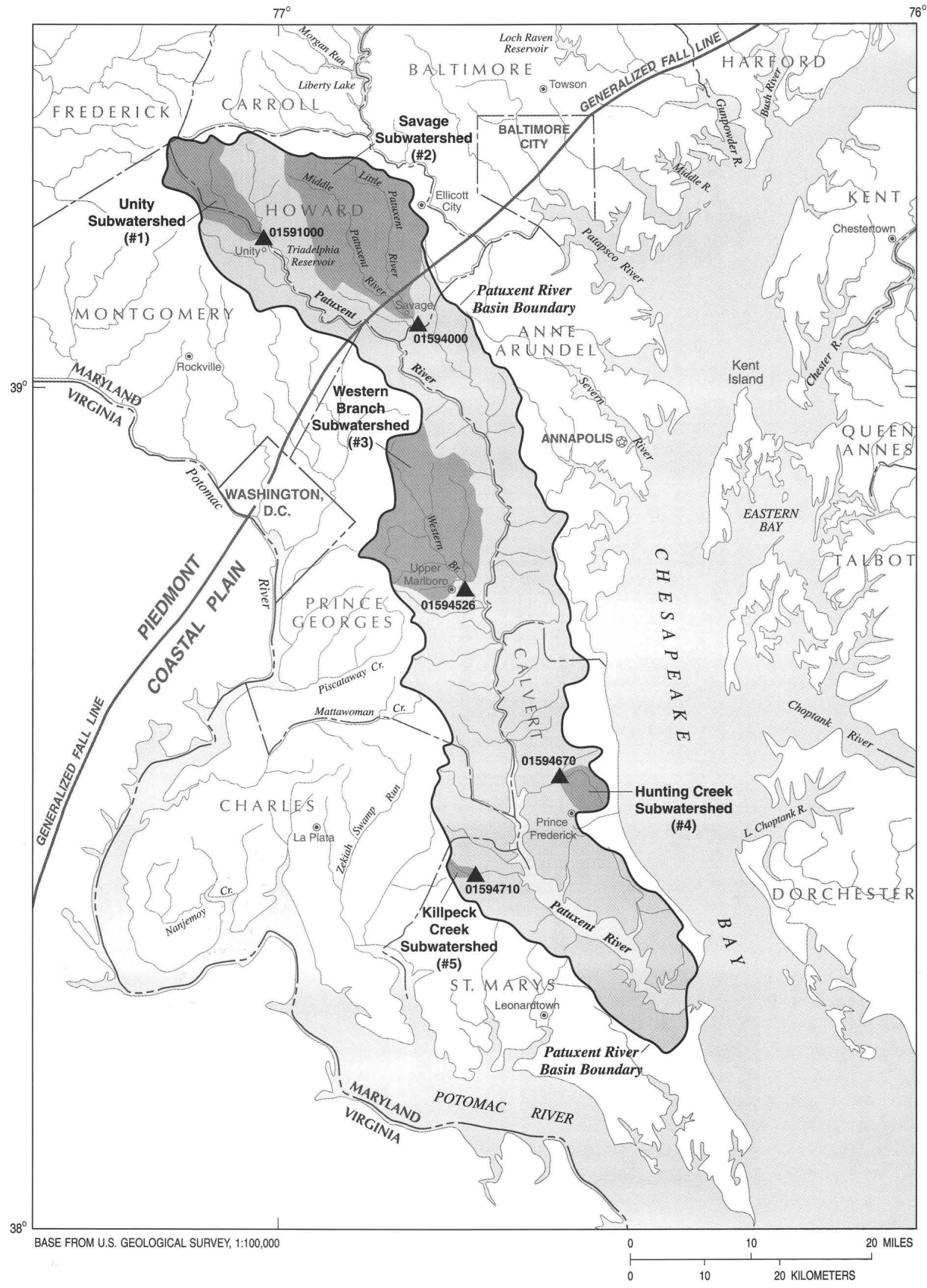

EXPLANATION

01594710
(\#5) STREAM-GAGING STATION AND MONITORING SITE, AND USGS STATION IDENTIFICATION NUMBER. (Number in parentheses is Site Number referenced in text and tables.)

Figure 1. Location of monitoring sites and subwatersheds in the Patuxent River Basin. 
From 1985 to 1994 , urban and residential land use increased by approximately 10 percent in the Patuxent River Basin. Between 1990 and 1994, the percentage of total land cover in residential, commercial, industrial, and institutional use increased from about 17 percent to about 20 percent; the percentage of forest and brush land cover decreased from about 45 to 43.5 percent; and the percentage of agricultural land use decreased from about 28 to 27 percent (Voinov, 1998).

\section{Description of Monitoring Sites}

Five stream sites were selected for detailed hydrologic and water-quality monitoring to represent the physiographic provinces and mix of land use/land cover in the watershed (table 1). One site is located on the main stem of the Patuxent River, two are on major tributaries, and two are at the outlets of small basins that discharge to the Patuxent River estuary.

The subwatershed farthest upstream is monitored near Unity, Md. (site 1, fig. 1), where Route 97 crosses the main stem of the Patuxent, immediately upstream of the Triadelphia

Reservoir. The Unity subwatershed is typical of rural land use in the Piedmont part of the basin. A second Piedmont subwatershed is monitored just south of Savage, Md. (site 2, fig. 1), where Route 1 crosses the Little Patuxent River. The Savage subwatershed has mixed land use and the percentage of urban land use is increasing rapidly. The site is located just downstream of the confluence of the Middle and Little Patuxent Rivers, and the subwatershed includes the developed area of Columbia, Md.

Three sites are located below the Fall Line in the Coastal Plain Province. Western Branch is a large tributary that discharges directly to the Patuxent estuary. The water-quality-monitoring site (site 3, fig. 1) is on Western Branch at Upper Marlboro, Md. The site is located upstream from the major point-source dischargers on this tributary and includes some highly developed areas near the Washington, D.C. beltway. Two subwatersheds represent the numerous small Coastal Plain subwatersheds that are located along the Patuxent estuary in the lower part of the Patuxent watershed. In Calvert County, the Hunting Creek subwatershed is monitored (site 4, fig. 1) at the Route 263 crossing. In St. Marys County, the Killpeck Creek subwatershed is monitored (site 5, fig. 1) near Huntersville, Md.
There are no major dischargers of nutrients or sediment within these subwatersheds. Nonpoint sources of nitrogen include atmospheric deposition, commercial manure, fertilizers, and effluent from septic-tank systems commonly used in rural areas and low-density housing developments. Sediment is transported in the river basin through land development activities and erosional processes.

\section{Methods of Data Collection and Processing}

Both the USGS and the State of Maryland collected samples at the five monitoring sites in the Patuxent River Basin from 1986-96. The USGS performed more intensive sampling during storm events as well as fixed monthly sampling. The State of Maryland collected grab samples at fixed frequencies, which varied by site. Data sets from the two agencies were combined for analysis of selected water-quality constituents at the five sites.

\section{U.S. Geological Survey Water-Quality and Streamflow Data Collection}

The USGS collected surface-water-quality samples both manually and with automatic samplers for this study. Monthly samples were collected manually by use of a weighted-bottle sampler at the five sites with either the EqualDischarge-Increment (EDI) method or the EqualTransit-Rate (ETR) method described by Guy and Norman (1970). The EDI method requires collecting samples of equal volume from the centroid of equal-discharge increments along the river cross section. The ETR method requires collecting sample volumes proportional to the amount of flow at each of several equally spaced verticals along the river cross section.

Samples were collected by automatic samplers during high-discharge events at the five sites. Automated sampling devices initiated sampling as a stream reached a specified actuation level. Actuation levels were selected specifically for each site, and represent the discharge level above which the stream is considered dominated by surface runoff. The actuator "turned on" the sampler and flow meter as the actuation level was reached, and would collect a sample each time a programmed volume of water passed the intake. The sampler pumped the water from the stream or mixing chamber and stored it in separate sample bottles in its refrigerator until the sample could be processed. 
Table 1. Drainage area, physiographic province, and land use/land cover in five subwatersheds in the Patuxent River Basin

[Data from the Maryland State Office of Planning; $\mathrm{mi}^{2}$, square miles; $\Delta$, change in percentage land use/land cover 1985-94]

\begin{tabular}{|c|c|c|c|c|c|c|c|c|c|c|c|c|c|}
\hline \multirow{3}{*}{$\begin{array}{l}\text { Site } \\
\text { no. }\end{array}$} & \multirow{3}{*}{$\begin{array}{l}\text { USGS } \\
\text { station } \\
\text { no. }\end{array}$} & \multirow{3}{*}{ Site name } & \multirow{3}{*}{$\begin{array}{l}\text { Drainage } \\
\text { area } \\
\left(\mathrm{mi}^{2}\right)\end{array}$} & \multirow{3}{*}{$\begin{array}{l}\text { Physiographic } \\
\text { province }\end{array}$} & \multicolumn{9}{|c|}{ Percentage land use/land cover } \\
\hline & & & & & \multicolumn{3}{|c|}{ Agricultural } & \multicolumn{2}{|l|}{ Forest } & \multicolumn{4}{|c|}{ Urban } \\
\hline & & & & & 1985 & 1994 & $\Delta$ & 1985 & 1994 & $\Delta$ & 1985 & 1994 & $\Delta$ \\
\hline 1 & 01591000 & $\begin{array}{l}\text { Patuxent River } \\
\text { near Unity, Md. }\end{array}$ & 34.8 & Piedmont & 64 & 56 & -8 & 32 & 36 & +4 & 3 & 8 & +5 \\
\hline 2 & 01594000 & $\begin{array}{l}\text { Little Patuxent } \\
\text { River at } \\
\text { Savage, Md. }\end{array}$ & 98.4 & Piedmont & 35 & 29 & -6 & 32 & 28 & -4 & 31 & 42 & +11 \\
\hline 3 & 01594526 & $\begin{array}{l}\text { Western Branch } \\
\text { at Upper } \\
\text { Marlboro, Md. }\end{array}$ & 89.7 & Coastal Plain & 30 & 26 & -4 & 42 & 38 & -4 & 24 & 34 & +10 \\
\hline 4 & 01594670 & $\begin{array}{l}\text { Hunting Creek } \\
\text { near } \\
\text { Huntingtown, Md }\end{array}$ & 9.38 & Coastal Plain & 20 & 20 & 0 & 76 & 72 & -4 & 4 & 8 & +4 \\
\hline 5 & 01594710 & $\begin{array}{l}\text { Killpeck } \\
\text { Creek at } \\
\text { Huntersville, Md. }\end{array}$ & 3.26 & Coastal Plain & 26 & 21 & -5 & 63 & 56 & -7 & 8 & 23 & +15 \\
\hline
\end{tabular}

Through January 1991, flow-weighted compositing of automatic samples was often performed to reduce the number of samples sent to the laboratory for a particular storm. After that time, only discrete samples were analyzed. When many samples were collected during a storm, the hydrograph was used as the basis for defining composites or selecting discrete samples. Samples were composited or selected to represent the rising and falling limbs of the hydrograph, and the peak flow.

Sample water was transferred from the weighted-bottle sampler or the refrigerated automatic sample bottles into a holding device known as a churn splitter. The churn splitter allowed subsamples to be withdrawn while maintaining a uniform distribution of suspended matter in the composited sample. Subsamples for wholewater analysis and for suspended-sediment analysis were withdrawn from the churn splitter while churning the sample water at a continuous rate of about 9 inches per second. The remaining sample was filtered on-site for dissolved- constituent analysis using a 0.45 -micron filter. Whole-water and filtered subsamples were transported to the Maryland Department of Health and Mental Hygiene (MDHMH) laboratory within 48 hours for nutrient and total suspended-solids analysis. A whole-water subsample was also shipped to an approved USGS sediment laboratory for suspended-sediment analysis.

Discharge measurements were made using standard USGS streamflow-gaging procedures (Buchanan and Somers, 1982). Monthly visits to the five sites included discharge measurements to verify or adjust the discharge rating. Further details on stage measurement or discharge calculation are described by Carter and Davidian (1968).

\section{State of Maryland Water-Quality Data Collection}

The State of Maryland collected grab samples at several long-term monitoring sites in the Patuxent River Basin [Bruce Michael, Maryland Department of Natural Resources (MDDNR), oral commun., 1998]. Monthly samples from the 
Patuxent River site (site 1, fig. 1) were collected as part of the State's Core Sampling Program. Approximately 20 samples a year were collected at fixed intervals at the Western Branch site (site 3, fig. 1) as part of the State's Slack Water Survey (Bruce Michael, oral commun., 1998). Waterquality samples from the Core Sampling Program were analyzed at the MDHMH laboratory during the entire study period. Samples from the Slack Water Survey were analyzed at the MDHMH laboratory until July 1990 , after which time the Chesapeake Biological Laboratory (CBL) was used. Interlaboratory comparisons between MDHMH and CBL were satisfactory (Bruce Michael, oral commun., 1998).

\section{Data Used In Analyses}

Five constituents were selected for analysis and load estimation-total nitrogen, nitrite plus nitrate, total phosphorus, total suspended solids, and suspended sediment. Total nitrogen is calculated as the sum of ammonium-nitrogen and organic nitrogen, determined by the total kjeldahl method (Fishman and Friedman, 1989), and nitrite plus nitrate, determined by colorimetry (U.S. Environmental Protection Agency, 1979). Total phosphorus also is determined by colorimetry (U.S. Environmental Protection Agency, 1979). During the study period, different pieces of equipment have been used by the MDHMH laboratory for colorimetry analyses, with varying detection limits depending upon the range of the concentrations measured. Total suspended solids and suspended sediment are both measures of the amount of particulate matter in the sample. Total suspended-solids concentration is determined by performing gravimetric analysis on a subsample that is collected from the whole sample using a graduated cylinder (American Public Health Association, 1975). Suspended-sediment concentration is determined by performing gravimetric analysis on the entire volume of a sample that was collected solely for that analysis (Guy, 1969). Both total suspended-solids and suspended-sediment analyses were performed on USGS samples to allow comparison with other studies that have used either water-quality constituent.

Estimated loads and yields of total nitrogen, nitrite plus nitrate, total phosphorus, total suspended solids, and suspended sediment for the study period 1986-96 were determined from the combined data sets of the USGS and the State of
Maryland. If duplicates were obtained during sampling, then the measured concentrations from the first sample were included.

Complete records of daily-mean discharge were available for most of the monitoring sites throughout the study period; however, Western Branch and Hunting Creek each have several years of missing record. Discharge data from the Western Branch site were not available from May 1989 through March 1992 because all of the gaging and sampling equipment was removed during road construction. Complete discharge records were not available for the Hunting Creek site during water years 1986, 1987, or 1988, because of sporadic equipment failure.

\section{Quality-Assurance Program}

Various types of quality-assurance data were collected during the study period to evaluate bias and variability due to sampling and laboratory analysis. As part of the Patuxent study, the USGS collected trip and field blanks, and duplicates of monthly EDI or ETR samples. In addition, the USGS performed a more detailed qualityassurance study comparing automatically collected samples to EDI or ETR samples at the Little Patuxent River (site 2, fig. 1) in water year 1993 (Koterba and others, 1994).

Blank-water samples collected by the USGS for this study were analyzed to determine bias in reporting due to field or laboratory contamination (fig. 2). Trip blanks were collected from 1986-91 and were made by filling a sample bottle with commercial distilled water, transporting it to the field site, and submitting it with the environmental samples to the laboratory. Field blanks were collected from 1992-95, and were made by passing laboratory-grade inorganic-free or deionized water through the sampling equipment at a site, processing this rinse water through the churn splitter and filtering apparatus, and sending it to the laboratory with other environmental samples.

Nitrite plus nitrate and total nitrogen were detected in the trip blanks. This detection may be due to the nutrients that are normally present in commercial distilled water. Commercial distilled water was used because no laboratory-grade inorganic-free water was available during the earlier years of this study. Blanks are no longer collected using commercially prepared water. 

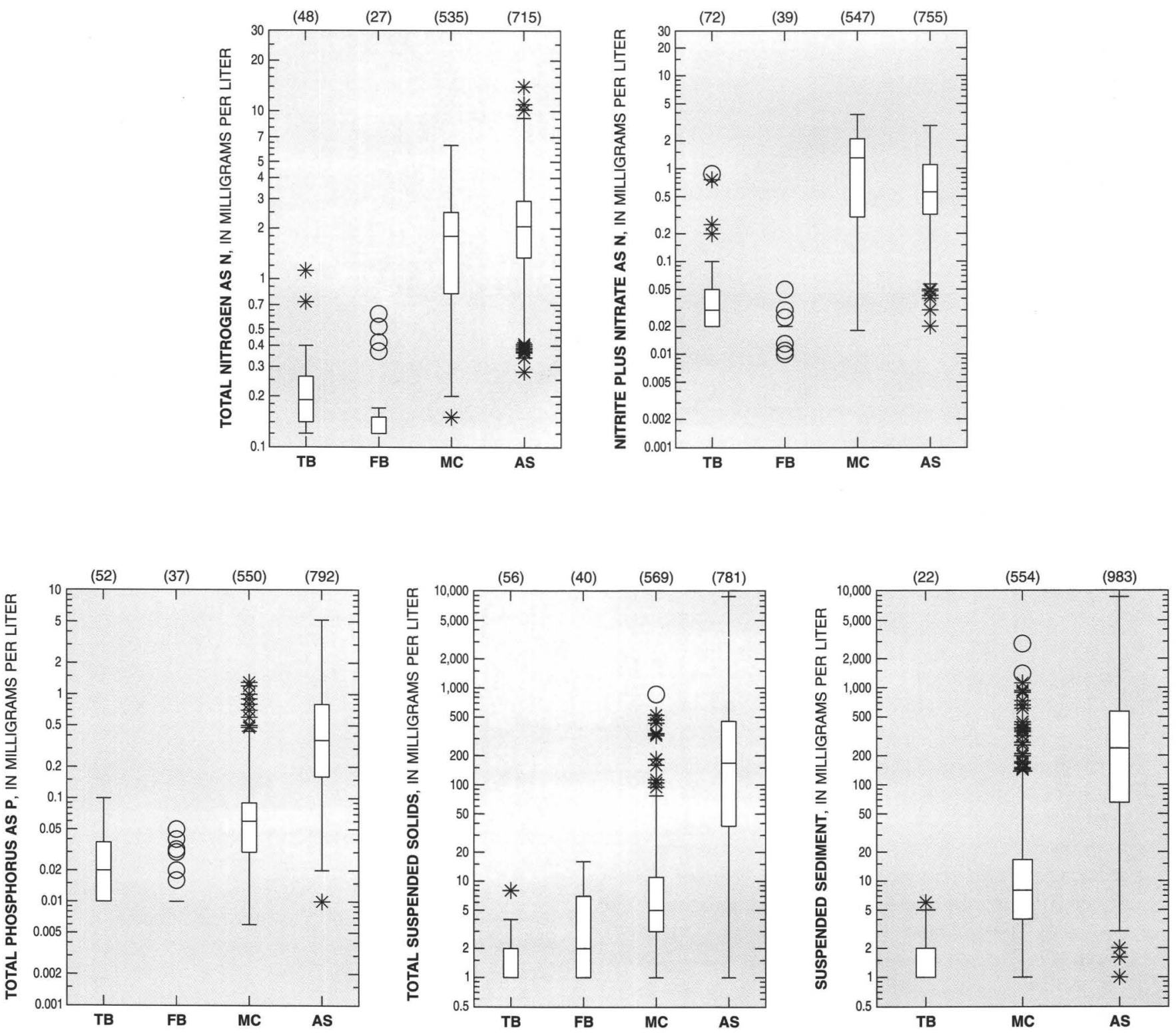

\section{EXPLANATION}

TB TRIP BLANK CONCENTRATIONS

FB FIELD BLANK CONCENTRATIONS

MC MONTHLY EDI OR ETR SAMPLE CONCENTRATIONS

AS AUTOMATIC-SAMPLE CONCENTRATIONS
(22) Number of observations

0 Outlier data value greater than 3 times the interquartile range outside the quartile

* Outlier data value less than or equal to 3 times and greater than 1.5 times the interquartile range outside the quartile

Data value less than or equal to 1.5 times the interquartile range outside the quartile

75th percentile

Median

25th percentile

Figure 2. Nutrient and sediment concentrations in quality-control blanks and stream samples collected by the U.S. Geological Survey, Patuxent River Basin, 1986-96. 
Duplicate samples collected by the USGS for this study were used to evaluate laboratory precision. The USGS duplicates, except for those collected during the more detailed study (Koterba and others, 1994), were collected sporadically at the five sites during monthly sampling trips. Duplicates from the automatic sampler were not collected because of the difficulty in collecting sufficient water for multiple samples. For this reason, the precision of concentrations typically measured at high flows was not evaluated.

The USGS duplicate samples were processed as split samples from the churn splitter. The State of Maryland also measured laboratory precision by splitting grab samples. Plots of duplicate sample data (fig. 3) show good repeatability of results for nitrogen over the range of values most often reported by the laboratory. The total suspended-solids and total-phosphorus precision is not as good for the low range of values represented. Most loading of total phosphorus and total suspended solids, however, comes during high-flow events, during which streams generally carry higher loads of phosphorus and sediment than those represented by the duplicates.

As part of the detailed USGS quality-assurance study at the Little Patuxent River site, data from river samples collected manually for selected storms were compared with concurrent data from the automatic sampler (Koterba and others, 1994). This was performed to ensure that the concentrations in point samples collected by the automatic sampler were representative of concentrations in the entire cross section of the streamflow. The results of this quality-assurance study showed that statistically similar nutrientconcentration data can be obtained using either the automatic sampler or manually composited EDI or ETR samples. Concentrations of suspended sediment in manual samples, however, exceeded concentrations from samples collected by the automatic sampler during higher flows (Koterba and others, 1994). No correction factor was applied to the sediment-concentration data from the automatic sampler at the Little Patuxent River site or at any of the other sites.

\section{Methods of Analysis}

Statistical regression was the principal method of analysis used in this interpretation of the waterquality data. Regression analysis was used to explain the variability in the concentration data, and the resulting relations between concentration, discharge, time, and seasonality were used to estimate concentrations, loads, and trends throughout the entire period.

Hydrograph separation is a numerical technique for separating the base-flow (ground water) and runoff (surface or stormflow water) components of streamflow. Hydrograph separation was performed to determine which samples were base-flow samples and which were stormflow samples. The concentrations of nutrients and sediment in base-flow samples were used with the base-flow discharge record to estimate base-flow loads. All of the concentration data were used to estimate total loads, yields, and trends.

\section{Hydrograph Separation}

A large percentage of streamflow in the Patuxent River Basin is derived from ground water. A smaller percentage enters the river directly from surface or near-surface runoff during storm events. The partitioning of constituent loading into surface-runoff and base-flow components is very important in designing effective nonpoint-source management strategies. For instance, if most of the nutrient and sediment load that enters the river is transported in surface runoff, detention ponds that capture surface runoff during storm events may be part of an appropriate management strategy. However, if a larger percentage of the load enters the river from ground-water discharge, appropriate management practices may include changes in fertilizerapplication rates, crop rotation, or septic-tank placement.

The local-minimum method was used for hydrograph separation (Sloto and Crouse, 1996). If a water-quality sample was collected on a day when the separated base-flow discharge was within 30 percent of the mean-daily discharge, the sample was classified as a "base-flow" sample. "Base-flow" samples included water from groundwater discharge to the stream and point-source contributions during low-flow conditions.

Other samples were classified as "stormrunoff" samples. "Storm-runoff" samples included water from ground-water discharge, interflow, point sources, and surface runoff. Most automatically collected samples were classified as storm-runoff samples because the automatic samplers were programmed to activate during the high stages that generally occur during storm 

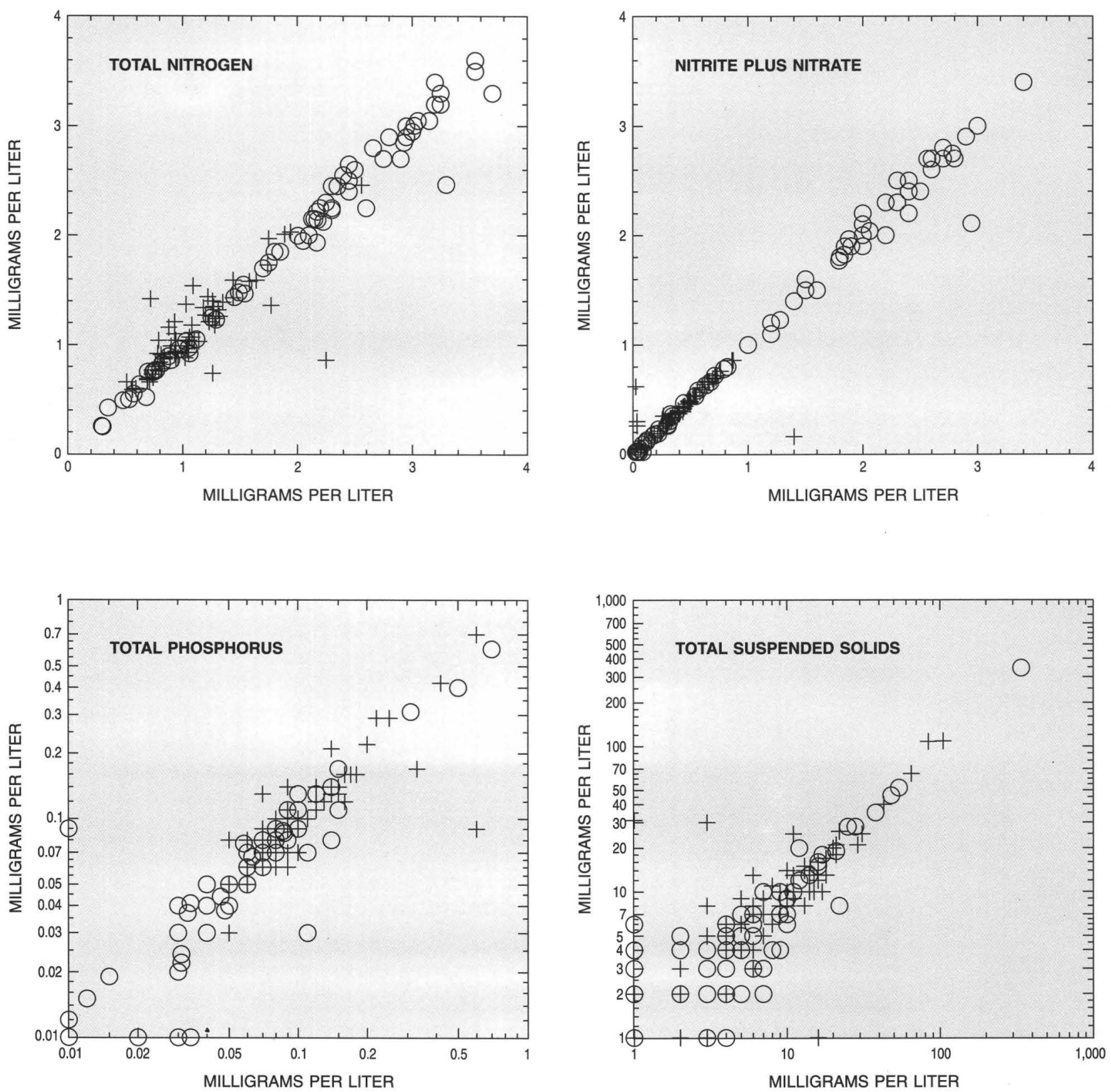

EXPLANATION

+ STATE OF MARYLAND DUPLICATE SAMPLES

U.S. GEOLOGICAL SURVEY DUPLICATE SAMPLES

Figure 3. Nutrient and sediment concentrations in duplicate samples collected by the U.S. Geological Survey and the State of Maryland, Patuxent River Basin, 1986-96. 
events. Monthly USGS samples and State of Maryland grab samples were classified as a combination of storm-runoff and base-flow samples.

\section{Concentration and Load Estimation}

The seven-parameter multivariate unbiased estimator model described by Cohn and others (1989) is a statistical regression model that is used to estimate concentrations and loads on nonsample days on the basis of trend, seasonality, and discharge. The version of the model used in this analysis includes an adjusted maximum-likelihood estimator, which allows use of data sets containing censored values (Cohn, 1988; Cohn, 1995). The model also includes a "bias correction factor" (Bradu and Mundlak, 1970) to account for bias introduced by the retransformation from log to real space.

The model has a maximum of seven independent parameters: an intercept, two discharge parameters and four time parameters. Independent parameters in the model are both linear and nonlinear. A quadratic discharge parameter is included to account for the possibility of a nonlinear log relation between concentration and discharge. Similarly, linear and quadratic time parameters are included to account for possible nonlinear trends in the long-term average concentration of a constituent. Cyclical variations in concentration often occur on a seasonal basis; thus, trigonometric functions are included to account for possible seasonal effects. $\bar{Q}$ and $\bar{T}$ are "centering" parameters that are defined to reduce covariance among the independent parameters and enhance estimate precision. In the model, dailydischarge data and water-quality data were used to calibrate a multiple regression equation of the form:

$$
\begin{aligned}
\ln (C) & =\beta_{0}+\beta_{1} \ln [Q / \bar{Q}] \\
+ & \beta_{2}\{\ln [Q / \bar{Q}]\}^{2}+\beta_{3}[T-\bar{T}] \\
+ & \beta_{4}[T-\bar{T}]^{2}+\beta_{5} \sin [2 \pi T] \\
+ & \beta_{6} \cos [2 \pi T]+\varepsilon,
\end{aligned}
$$

where

$$
\begin{aligned}
& \text { In = natural logarithm function; } \\
& \beta_{0}-\beta_{6}=\text { beta coefficients of the explanatory } \\
& \text { variables; } \\
& C=\text { measured concentration }(\mathrm{mg} / \mathrm{L}) \text {; } \\
& Q \quad=\text { mean-daily discharge on the day the } \\
& \text { sample was taken }\left(\mathrm{ft}^{3} / \mathrm{s}\right) \text {; } \\
& \bar{Q}=\text { centered discharge }\left(\mathrm{ft}^{3} / \mathrm{s}\right) \text {; } \\
& T=\text { time, converted to decimal form }(\mathrm{yr}) ; \\
& \bar{T} \quad=\quad \text { centered time, converted to decimal } \\
& \text { form (yr); and } \\
& \varepsilon=\text { combined independent random error, }
\end{aligned}
$$

Daily loads, the product of the daily estimated constituent concentrations and the mean-daily discharge, are estimated using the model results. For predicting concentrations and loads during base-flow conditions, concentrations from baseflow samples and the separated base-flow component of the discharge record are used in the model. Annual loads are the sum of the daily loads for a year and can be converted to annual yields by dividing by the drainage area of the monitored site. Annual water yields are determined by taking the mean-annual discharge and dividing by the drainage area of the monitored site.

\section{Trend Analysis}

The percentage change in concentration with time at a location can be estimated from the multivariate regression equation (1) above to obtain a trend estimate for the period over which the model was calibrated (Darrell and others, in press). The decimal time beta coefficient $\beta_{3}$ from equation (1) and the period of time $(\Delta t)$ for which a trend is to be estimated are substituted in equation (2) to obtain the trend:

$$
\text { trend, in percent }=100\left(\mathrm{e}^{\beta 3 \Delta t}-1\right)
$$

Trends were calculated for all constituents for which a load was determined and are expressed as a percentage change for a period of time $(\Delta t)$. A positive trend indicates an increase in the concentration of a constituent, if flow were constant for the time period. A negative trend indicates a 
decrease in the concentration of a constituent, if the flow were constant for the period of time $(\Delta t)$. A trend was considered significant if the $p$-value for $\beta_{3}$ was $\leq 0.05$, which corresponds to the 95-percent confidence interval. A $p$-value of $\leq 0.05$ would mean that the trend computed for $\beta_{3}$ exists in the data and is not a result of random variation.

\section{Concentrations, Trends, and Loads of Nutrients and Sediment}

Progress toward nutrient-reduction goals for the year 2000 set by the Chesapeake Bay Program (CBP) (USEPA, 1998) for nonpoint sources in the Patuxent River Basin can be assessed by evaluating the concentrations, trends, and estimated loads from the five subwatersheds: Patuxent River near Unity, Little Patuxent River at Savage, Western Branch at Upper Marlboro, Hunting Creek near Huntingtown, and Killpeck Creek at Huntersville. These subwatersheds make up approximately 25 percent of the total basin area, mainly in the Piedmont part of the basin. These subwatersheds contributed approximately 40 percent of the goal for point- and nonpointsource nitrogen load and approximately 70 percent of the goal for point- and nonpoint-source phosphorus load for the Patuxent River Basin.

Annual loads of nutrients and sediment are highly dependent on the hydrologic conditions in a given year. Although the nutrient-reduction goals are based upon load reduction, the effectiveness of nutrient-reduction strategies may be better assessed by removing this natural hydrologic variability. Unlike the load estimates, the trends in concentrations described below are determined by the statistical regression analysis and are flow-adjusted.

\section{Summary of Measured Concentrations}

Nutrient and sediment concentrations are summarized by streamflow conditions at each of the five sites (figs. 4A-E). At many sites, the sampling frequency varied during the study period (table 2) depending on the amount of precipitation in a particular year, but sampling frequency generally increased, especially during storm events, as sampling methods and equipment were refined and improved. This increase should not significantly affect the estimated loads and trends, because the model is flow-adjusted. The annual storm-sampling rate was determined as the percentage of the total number of storms that were sampled at least once. Not all water-quality constituents were measured in each storm sample.

On the basis of the model results for the beta coefficient of the linear-discharge parameter (column 4, table 3), discharge is statistically significant in explaining the concentrations of total nitrogen, nitrite plus nitrate, total phosphorus, total suspended solids, and suspended sediment at all of the sites. Concentrations increased with increasing discharge, with the exception of nitrite plus nitrate, which decreased with increasing discharge at the Patuxent River (site 1), Little Patuxent River (site 2), and Killpeck Creek sites (site 5).

\section{Trends in Concentrations}

Trends in concentrations with time and the associated 95-percent confidence intervals (fig. 5) were determined using model results for the beta coefficient of the linear time parameter (column 6, table 3 ) and the beta coefficient's $p$-value as explained in the Methods of Analysis section. These trends account for natural hydrologic variability due to discharge; natural hydrologic variability may make the trend difficult to discern when concentration is plotted as a simple time series (fig. 6).

There were statistically significant increases in estimated concentrations of total nitrogen and nitrite plus nitrate at the Little Patuxent River and Killpeck Creek, the two sites with the most development during the study period. Concentrations of total nitrogen and nitrite plus nitrate 
Table 2. Percentage of storms sampled at five monitoring sites in the Patuxent River Basin, 1986-96

[A storm event is defined as a day or continuous days in which the base-flow discharge makes up less than 70 percent of the mean-daily discharge. A storm is considered sampled if at least one sample is collected during the storm; -, no data available]

\begin{tabular}{|c|c|c|c|c|c|}
\hline \multirow[b]{3}{*}{$\begin{array}{l}\text { Water } \\
\text { Year }\end{array}$} & \multicolumn{5}{|c|}{ Sampled storms, in percent of all storms } \\
\hline & \multicolumn{5}{|c|}{ Site name [site no. (refer to fig. 1)] } \\
\hline & $\begin{array}{l}\text { Patuxent River } \\
\text { near Unity (1) }\end{array}$ & $\begin{array}{l}\text { Little Patuxent River } \\
\text { at Savage (2) }\end{array}$ & $\begin{array}{l}\text { Western Branch at } \\
\text { Upper Marlboro (3) }\end{array}$ & $\begin{array}{l}\text { Hunting Creek near } \\
\text { Huntingtown (4) }\end{array}$ & $\begin{array}{l}\text { Killpeck Creek at } \\
\text { Huntersville (5) }\end{array}$ \\
\hline 1986 & 4 & 4 & 24 & - & 6 \\
\hline 1987 & 33 & 3 & 24 & - & 5 \\
\hline 1988 & 36 & 8 & 20 & - & 3 \\
\hline 1989 & 26 & 19 & 46 & 17 & 41 \\
\hline 1990 & 32 & 19 & - & 28 & 38 \\
\hline 1991 & 35 & 24 & - & 18 & 33 \\
\hline 1992 & 38 & 24 & 45 & 21 & 47 \\
\hline 1993 & 50 & 42 & 38 & 23 & 26 \\
\hline 1994 & 51 & 32 & 34 & 18 & 24 \\
\hline 1995 & 43 & 26 & 39 & 22 & 12 \\
\hline 1996 & 36 & 44 & 43 & 14 & 12 \\
\hline
\end{tabular}


(A) Patuxent River near Unity
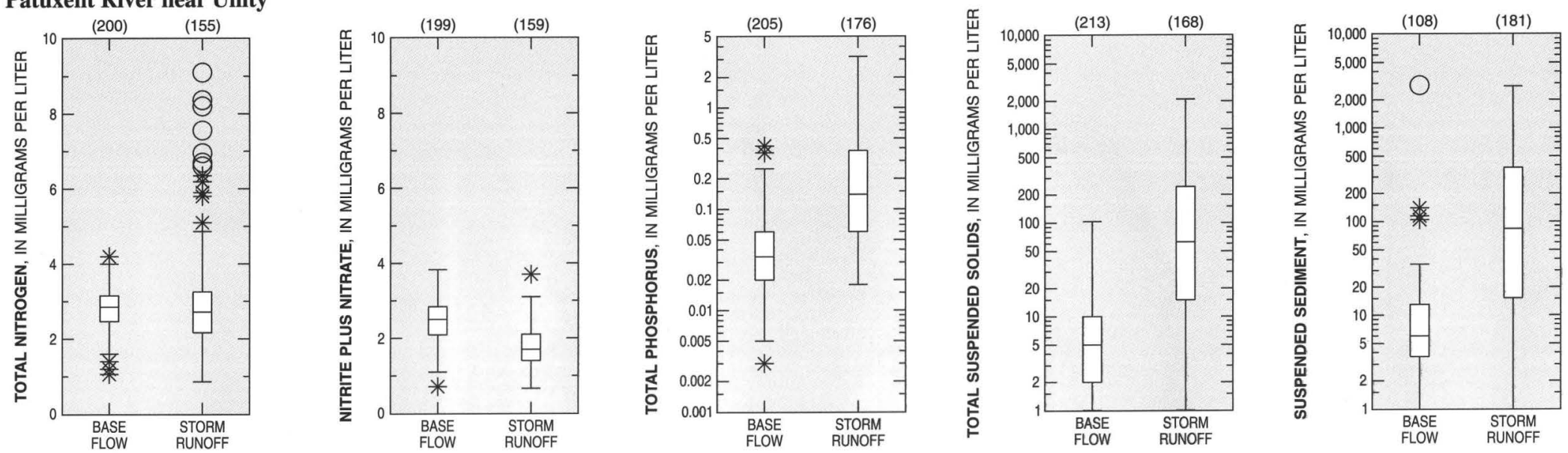

(B) Little Patuxent River at Savage
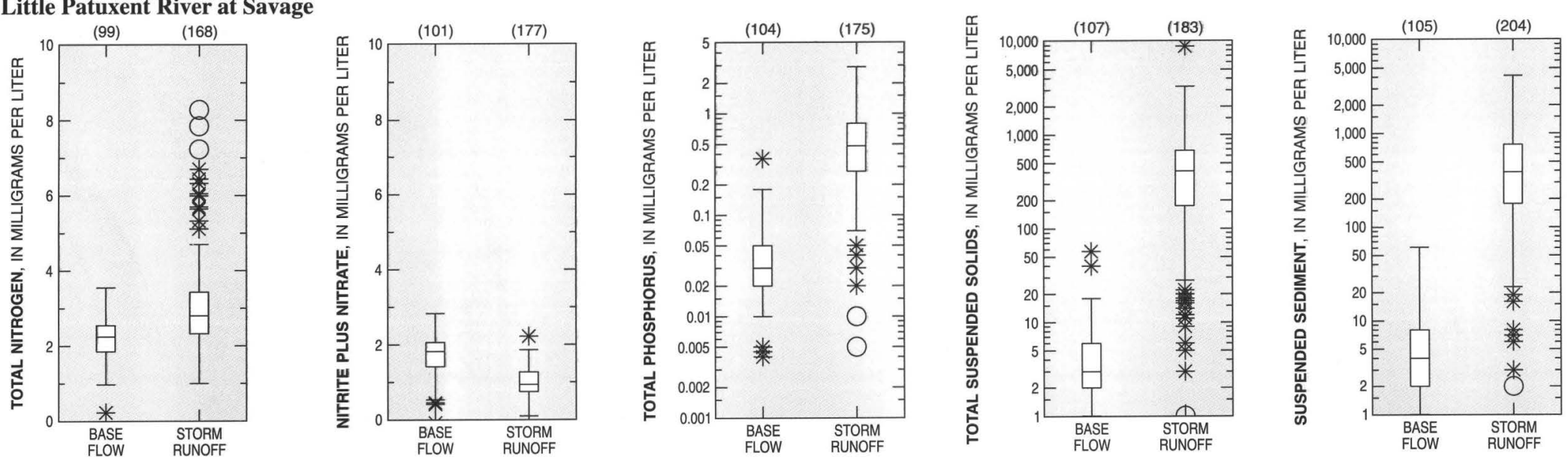

C) Western Branch at Upper Marlboro
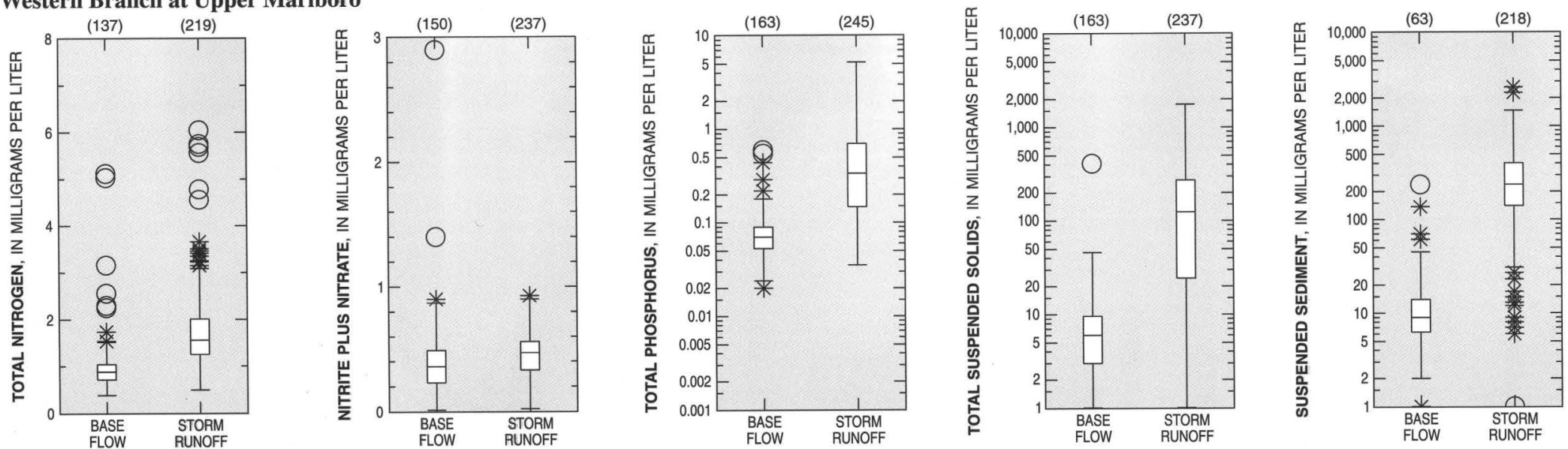
(D) Hunting Creek near Huntingtown
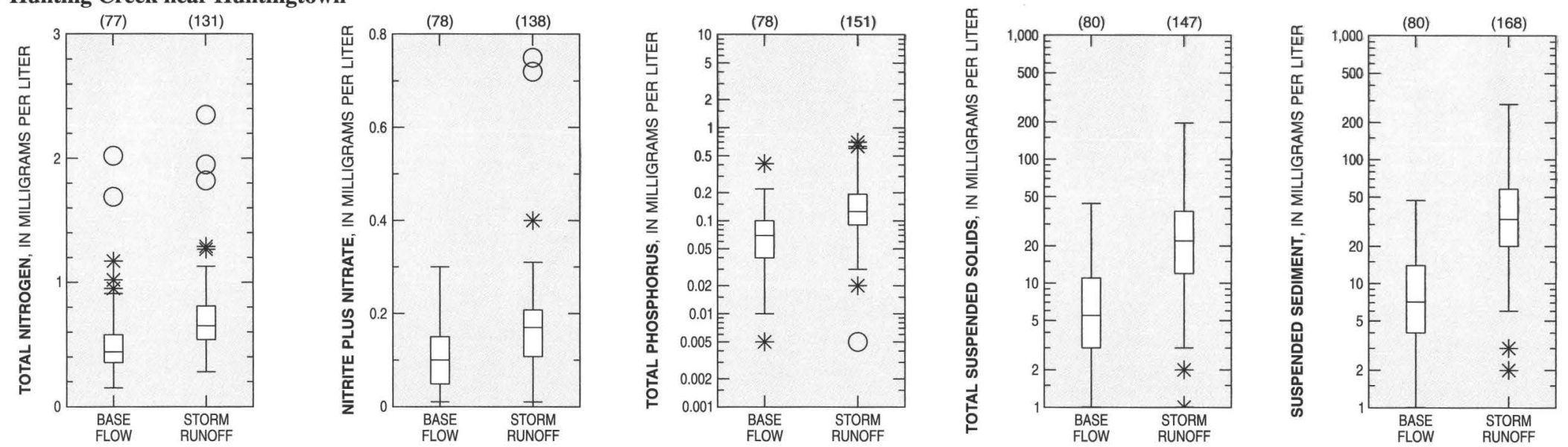

(E) Killpeck Creek at Huntersville
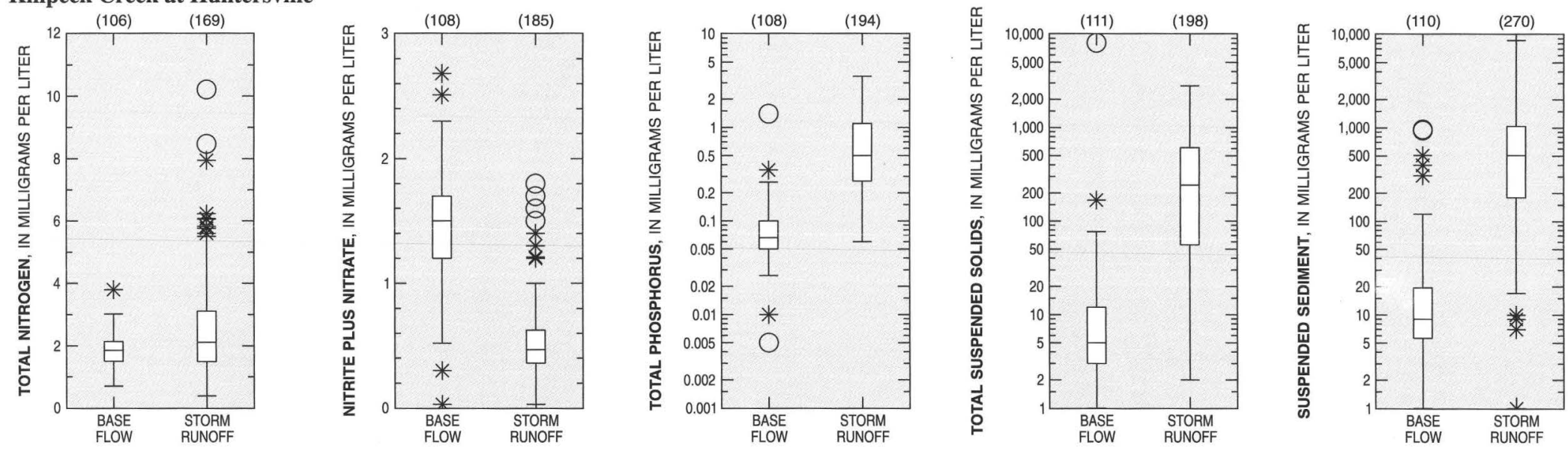

\section{EXPLANATION}

(105) Number of observations

O Outlier data value greater than 3 times the interquartile range outside the quartile

* Outlier data value less than or equal to 3 times and greater than 1.5 times the interquartile range outside the quartile

Data value less than or equal to 1.5 times the interquartile range outside the quartile

75th percentile

Median

25th percentile

Figure 4. Measured concentrations of nutrients and sediment in base-flow and storm-runoff samples collected from subwatersheds in the Patuxent River Basin, 1986-96 at: (A) Patuxent River near Unity (site 1), (B) Little Patuxent River at Savage (site 2), (C) Western Branch at Upper Marlboro (site 3), (D) Hunting Creek near Huntingtown (site 4), and (E) Killpeck Creek at Huntersville (site 5). 
Table 3. Regression-model beta coefficient estimates and diagnostics, 1986-96

[ $l n$, natural logarithm function; $\beta_{0}-\beta_{6}$, beta coefficients of the explanatory variables; $Q$, mean daily discharge on the day the sample was taken $\left(\mathrm{ft}^{3} / s\right) ; \bar{Q}$, centered discharge $\left(\mathrm{ft}^{3} / \mathrm{s}\right) ; \mathrm{ft}^{3} / s$, cubic feet per second; $T$, time, converted to decimal form (yr); $\bar{T}$, centered time, converted to decimal form; yr, year; $s$, standard error of the regression; $r^{2}$, fraction of the variance explained by regression; *, coefficient is statistically significant]

\begin{tabular}{|c|c|c|c|c|c|c|c|c|c|c|}
\hline \multirow[t]{2}{*}{ Monitoring site } & \multirow[t]{2}{*}{ Constituent } & \multirow{2}{*}{$\begin{array}{c}\text { Constant } \\
\qquad \beta_{0}\end{array}$} & \multirow{2}{*}{$\begin{array}{c}\ln (Q / \bar{Q}) \\
\beta_{1}\end{array}$} & \multirow{2}{*}{$\begin{array}{c}\{\ln [Q / \bar{Q}]\}^{2} \\
\boldsymbol{\beta}_{\mathbf{2}}\end{array}$} & \multirow{2}{*}{$\begin{array}{c}(T-\bar{T}) \\
\beta_{3}\end{array}$} & \multirow{2}{*}{$\begin{array}{c}(T-\bar{T})^{2} \\
\beta_{4}\end{array}$} & \multirow{2}{*}{$\begin{array}{c}\sin (2 \pi T) \\
\beta_{5}\end{array}$} & \multirow{2}{*}{$\begin{array}{c}\cos (2 \pi T) \\
\beta_{6}\end{array}$} & \multirow[b]{2}{*}{$s$} & \multirow[b]{2}{*}{$r^{2}$} \\
\hline & & & & & & & & & & \\
\hline \multirow{5}{*}{$\begin{array}{l}\text { Patuxent River } \\
\text { near Unity }\end{array}$} & Total nitrogen ${ }^{a}$ & $1.122^{*}$ & $0.081^{*}$ & $-0.057^{*}$ & -0.008 & 0.0001 & $-0.051^{*}$ & -0.027 & 0.266 & 16.0 \\
\hline & $\begin{array}{l}\text { Nitrite plus } \\
\text { nitrate }\end{array}$ & $.816^{*}$ & $-.101^{*}$ & $-.064 *$ & .007 & -.002 & .009 & $.047^{*}$ & .264 & 34.4 \\
\hline & Total phosphorus & $-2.346^{*}$ & $.842^{*}$ & .001 & $-.147 *$ & .003 & $-.551^{*}$ & $-.617^{*}$ & .948 & 52.3 \\
\hline & $\begin{array}{l}\text { Total } \\
\text { suspended } \\
\text { solids }\end{array}$ & $3.022 *$ & $1.109 *$ & .019 & .010 & .001 & $-.386 *$ & $-.767 *$ & 1.385 & 50.3 \\
\hline & $\begin{array}{c}\text { Suspended } \\
\text { sediment }\end{array}$ & $3.677^{*}$ & $1.063^{*}$ & -.073 & $-.082 *$ & .010 & $-.891 *$ & $-.820 *$ & 1.640 & 40.4 \\
\hline \multirow{5}{*}{$\begin{array}{l}\text { Little } \\
\text { Patuxent River } \\
\text { at Savage }\end{array}$} & Total nitrogen & .957 & $.144^{*}$ & $-.024^{*}$ & $.013^{*}$ & -.002 & .009 & .015 & .275 & 37.2 \\
\hline & $\begin{array}{l}\text { Nitrite plus } \\
\text { nitrate }\end{array}$ & $.301^{*}$ & $-.231 *$ & $-.052^{*}$ & $.030^{*}$ & -.001 & $.219^{*}$ & $.134^{*}$ & .310 & 49.1 \\
\hline & Total phosphorus & $-1.764 *$ & $1.181^{*}$ & $-.069 *$ & $-.083 *$ & .006 & $-.453 *$ & $-.436 *$ & .957 & 66.8 \\
\hline & $\begin{array}{l}\text { Total } \\
\text { suspended } \\
\text { solids }\end{array}$ & $4.368 *$ & $1.721 *$ & $-.166^{*}$ & $.095^{*}$ & $-.030^{*}$ & $.660^{*}$ & $-.632 *$ & 1.378 & 73.3 \\
\hline & $\begin{array}{c}\text { Suspended } \\
\text { sediment }\end{array}$ & $4.331 *$ & $1.777 *$ & $-.125^{*}$ & $-.057 *$ & .011 & $-.508^{*}$ & $-.477^{*}$ & 1.147 & 76.9 \\
\hline
\end{tabular}


Table 3. Regression-model beta coefficient estimates and diagnostics, 1986-96-Continued

\begin{tabular}{|c|c|c|c|c|c|c|c|c|c|c|}
\hline \multirow[t]{2}{*}{ Monitoring site } & \multirow[t]{2}{*}{ Constituent } & \multirow{2}{*}{$\begin{array}{c}\text { Constant } \\
\qquad \beta_{0}\end{array}$} & \multirow{2}{*}{$\begin{array}{c}\ln (Q / \bar{Q}) \\
\beta_{1}\end{array}$} & \multirow{2}{*}{$\begin{array}{c}\{\ln [Q / \bar{Q}]\}^{2} \\
\beta_{2}\end{array}$} & \multirow{2}{*}{$\begin{array}{c}(T-\bar{T}) \\
\beta_{3}\end{array}$} & \multirow{2}{*}{$\begin{array}{c}(T-\bar{T})^{2} \\
\beta_{4}\end{array}$} & \multirow{2}{*}{$\begin{array}{c}\sin (2 \pi T) \\
\beta_{5}\end{array}$} & \multirow{2}{*}{$\begin{array}{c}\cos (2 \pi T) \\
\beta_{6}\end{array}$} & \multirow[b]{2}{*}{$s$} & \multirow[b]{2}{*}{$r^{2}$} \\
\hline & & & & & & & & & & \\
\hline \multirow{5}{*}{$\begin{array}{l}\text { Western Branch } \\
\text { at Upper Marlboro b }\end{array}$} & Total nitrogen & $.198^{*}$ & $0.238^{*}$ & -0.006 & -0.012 & 0.002 & -0.021 & $-0.086^{*}$ & 0.373 & 45.7 \\
\hline & $\begin{array}{l}\text { Nitrite plus } \\
\text { nitrate }\end{array}$ & $-.973 *$ & $.142^{*}$ & $-.045^{*}$ & .012 & .003 & $.224^{*}$ & .061 & .513 & 35.0 \\
\hline & Total phosphorus & $-1.856^{*}$ & $.621 *$ & $.055^{*}$ & $-.030^{*}$ & -.001 & $-.336 *$ & $-.418^{*}$ & .769 & 54.7 \\
\hline & $\begin{array}{l}\text { Total } \\
\text { suspended } \\
\text { solids }\end{array}$ & $2.912^{*}$ & $1.112^{*}$ & $.076^{*}$ & .034 & .002 & $-.347 *$ & $-.560 *$ & 1.053 & 71.0 \\
\hline & $\begin{array}{c}\text { Suspended } \\
\text { sediment }\end{array}$ & $4.434 *$ & $.996^{*}$ & $-.076^{*}$ & -.019 & -.002 & $-.236 *$ & $-.290 *$ & 1.044 & 60.6 \\
\hline \multirow{5}{*}{$\begin{array}{l}\text { Hunting Creek } \\
\text { near Huntingtown }{ }^{c}\end{array}$} & Total nitrogen & $-.623^{*}$ & $.130^{*}$ & $.045^{*}$ & $-.056^{*}$ & .000 & $-.131 *$ & $-.224 *$ & .351 & 29.4 \\
\hline & $\begin{array}{l}\text { Nitrite plus } \\
\text { nitrate }\end{array}$ & $-2.164^{*}$ & $.275^{*}$ & -.001 & $-.055^{*}$ & -.024 & .075 & .048 & .622 & 33.2 \\
\hline & Total phosphorus & $-2.499^{*}$ & $.302^{*}$ & $.045^{*}$ & $-.097^{*}$ & $.016^{*}$ & $-.359^{*}$ & $-.501 *$ & .690 & 32.9 \\
\hline & $\begin{array}{l}\text { Total } \\
\text { suspended } \\
\text { solids }\end{array}$ & $2.457^{*}$ & $.497 *$ & .018 & .010 & -.008 & $-.319 *$ & $-.522 *$ & .933 & 34.8 \\
\hline & $\begin{array}{c}\text { Suspended } \\
\text { sediment }\end{array}$ & $2.794^{*}$ & $.512^{*}$ & $.072 *$ & .006 & -.012 & $-.417^{*}$ & $-.501 *$ & .833 & 43.1 \\
\hline
\end{tabular}


Table 3. Regression-model beta coefficient estimates and diagnostics, 1986-96-Continued

\begin{tabular}{|c|c|c|c|c|c|c|c|c|c|c|}
\hline \multirow[t]{2}{*}{ Monitoring site } & \multirow[t]{2}{*}{ Constituent } & Constant & $\ln (Q / \bar{Q})$ & $\{\ln [Q / \bar{Q}]\}^{2}$ & $(T-\bar{T})$ & $(T-\bar{T})^{2}$ & $\sin (2 \pi T)$ & $\cos (2 \pi T)$ & & \\
\hline & & $\beta_{0}$ & $\beta_{1}$ & $\beta_{2}$ & $\beta_{3}$ & $\beta_{4}$ & $\beta_{5}$ & $\beta_{6}$ & $s$ & $r^{2}$ \\
\hline \multirow{5}{*}{$\begin{array}{l}\text { Killpeck Creek } \\
\text { at Huntersville }\end{array}$} & Total nitrogen & $0.632 *$ & $0.092 *$ & 0.021 & $0.020 *$ & $0.007 *$ & 0.021 & $-0.098 *$ & 0.415 & 13.5 \\
\hline & $\begin{array}{l}\text { Nitrite plus } \\
\text { nitrate }\end{array}$ & $-.272 *$ & $-.468 *$ & $-.033 *$ & $.030 *$ & .006 & $.182^{*}$ & $-.123 *$ & .459 & 60.6 \\
\hline & Total phosphorus & $-1.481^{*}$ & $.796 *$ & .019 & $-.051^{*}$ & .006 & -.207 & -.151 & .882 & 54.8 \\
\hline & $\begin{array}{l}\text { Total } \\
\text { suspended } \\
\text { solids }\end{array}$ & $3.855^{*}$ & $1.436^{*}$ & .044 & .059 & $-.033^{*}$ & $-.205^{*}$ & $-.365^{*}$ & 1.301 & 66.0 \\
\hline & $\begin{array}{c}\text { Suspended } \\
\text { sediment }\end{array}$ & $4.782^{*}$ & $1.464 *$ & -.050 & -.014 & $-.022 *$ & -.141 & $-.492 *$ & 1.299 & 66.0 \\
\hline
\end{tabular}

${ }^{a}$ Multiple analyses of total nitrogen concentrations on a single day are averaged to reduce serial correlation in model.

${ }^{b}$ Shortened calibration period due to missing data, 1989-1992.

${ }^{\mathrm{c}}$ Shortened calibration period due to missing data, 1986-1988. 


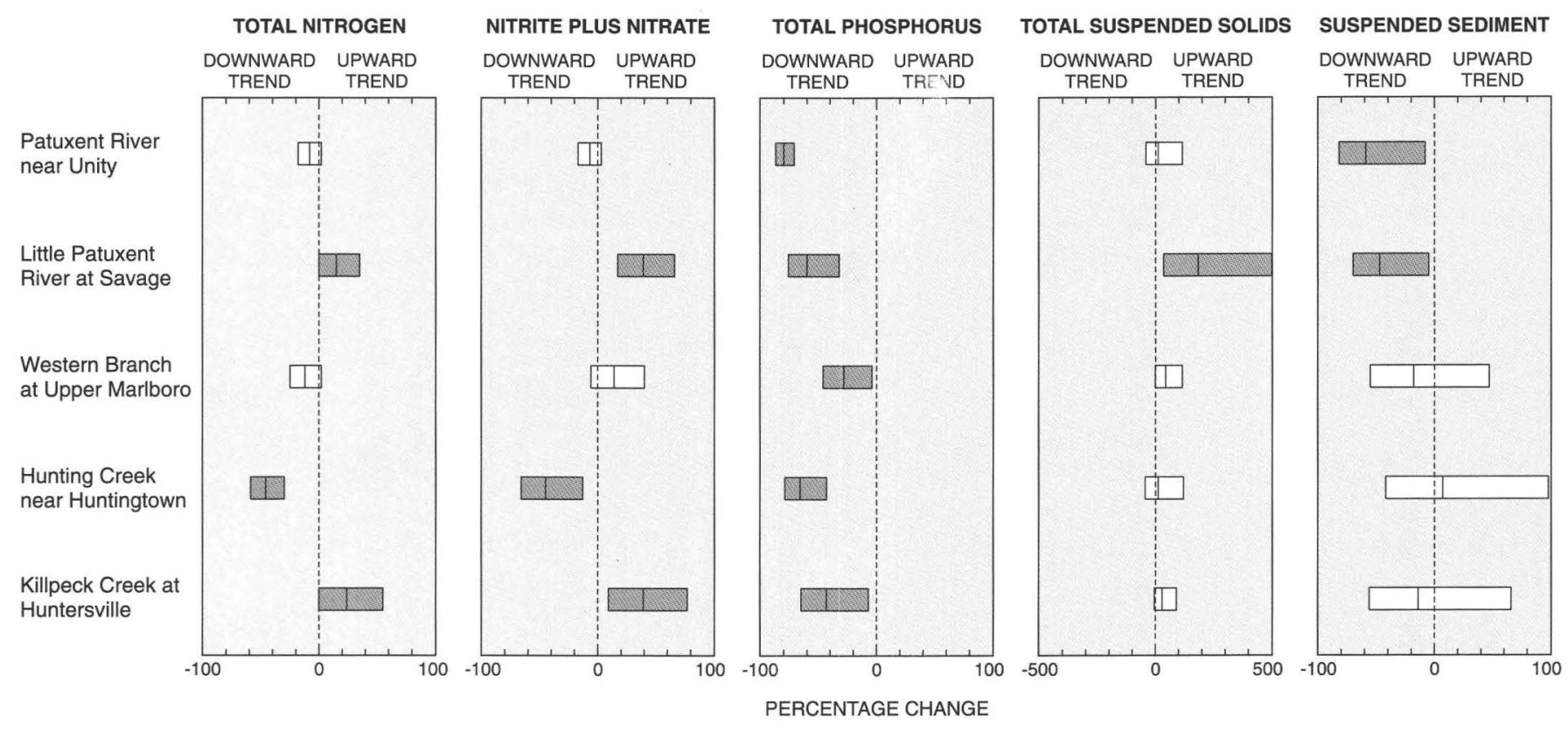

\section{EXPLANATION}

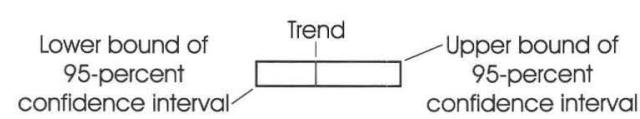

Figure 5. Trends in flow-adjusted concentrations of total nitrogen, nitrite plus nitrate, total phosphorus, total suspended solids, and suspended sediment at five monitoring sites in the Patuxent River Basin, 1986-96. [Confidence interval is 95 percent. Significant trend ( $p$-value $\leq 0.05$ ) is shaded and does not cross the zero (dashed) line.]
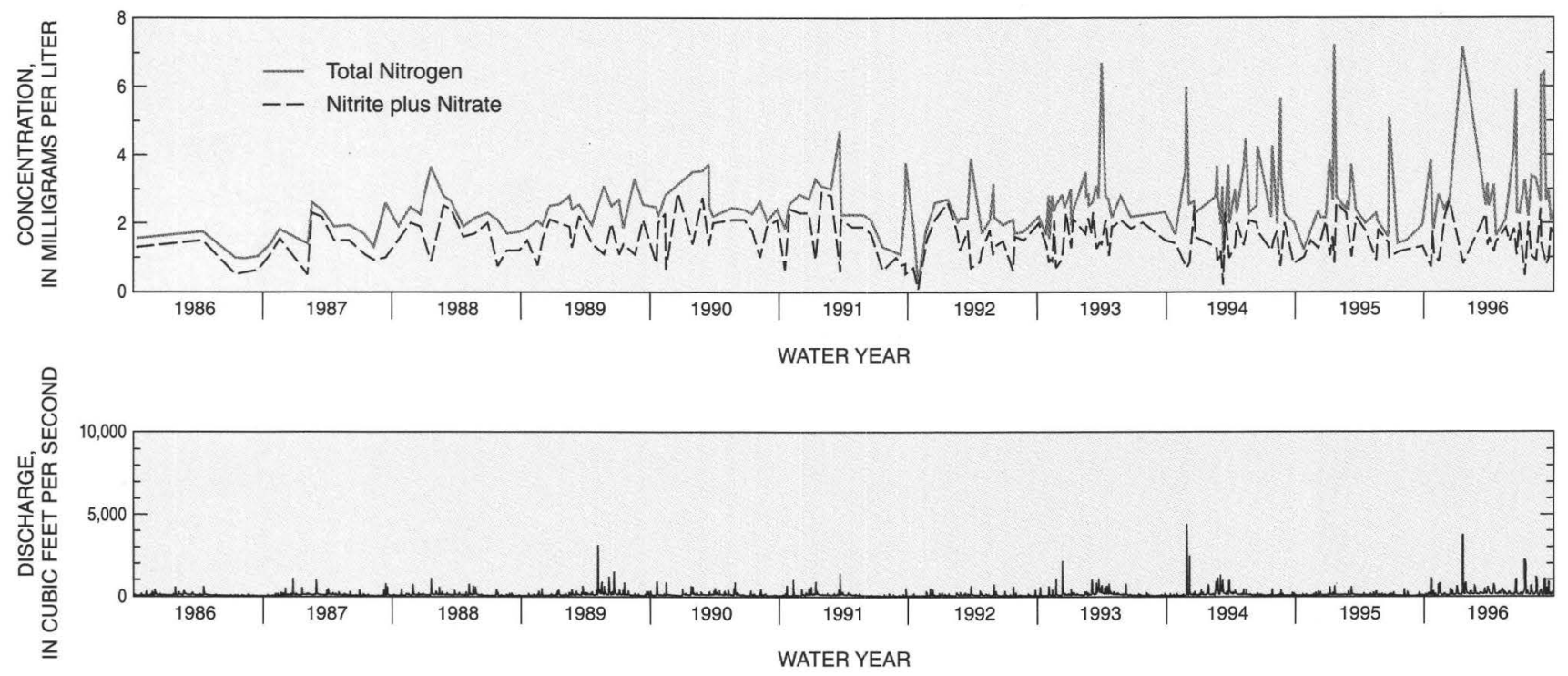

Figure 6. Nitrogen concentrations and mean-daily discharge at the Little Patuxent River at Savage, 1986-96. 
significantly decreased only at the Hunting Creek site. The Hunting Creek near Huntingtown subwatershed did not experience substantial development over the study period (see table 1). Estimated concentrations of total phosphorus decreased significantly with time at all sites in the basin. At Hunting Creek, the rate of the downward trend decreased in the latter years of the study; the beta coefficient for the time-squared variable was significant and positive (table 3 ). Total phosphorus was largely transported with particulate matter. Concentrations of total suspended solids, however, did not decrease with time at any site and concentrations of suspended sediment significantly decreased with time at the Patuxent River and Little Patuxent River sites (sites 1 and 2, fig. 1), which indicates that concentrations of total phosphorus may have decreased independently of sediment control at some sites. The decrease may have been due at least in part to the phosphate-detergent ban implemented in the late 1980's.

\section{Estimates of Nutrient and Sediment Loads}

While these five subwatersheds represent only 25 percent of the surface area of the Patuxent River Basin, the combined average-annual load of total nitrogen from these subwatersheds from 1993-96 was estimated to be 1.4 million pounds, and the average-annual load of nitrite plus nitrate was estimated to be 0.74 million pounds. The average-annual load of nitrite plus nitrate comprises slightly more than half of the averageannual load of total nitrogen. The combined average-annual total phosphorus load from these subwatersheds from 1993-96 was estimated to be 0.23 million pounds. The combined averageannual loads of suspended solids and suspended sediment from these subwatersheds from 1993-96 were estimated to be 260 and 275 million pounds, respectively. These loads were calculated from the estimates presented in tables 4-8.

\section{Base-Flow Component of Loads}

Base flow comprised most of the daily flow at all five monitored sites during the study period. The fraction of time during which base flow was dominant for individual sites ranged from 57-85 percent of the number of monitored days. On the basis of annual averages, base flow makes up between 50 (Western Branch) to 70 percent (Killpeck Creek) of the total discharge at each site during the study period.

Nutrient and sediment base-flow loadings were estimated for each of the five sites and reported as percentages of the total load. The Patuxent River and Killpeck Creek sites had the highest percentage of the loads of total nitrogen and nitrite plus nitrate transported during base flow. Most of the load of total phosphorus, total suspended solids, and suspended sediment was transported during storm events at each site. The percentages of total phosphorus, total suspended solids, and suspended-sediment loads that were transported by base flow were lowest at the most urbanized sites. The Hunting Creek site had the highest percentages of loads carried by base flow for these constituents. 
Table 4. Estimated loads and yield of total nitrogen at five monitoring sites in the Patuxent River Basin, 1986-96

[Load is in millions of pounds. Average yield is in millions of pounds per year per square mile. Average load and yield are calculated for years when all sites have data. Drainage area is in square miles taken from table 1 -site 1 drainage area $=34.8$; site 2 drainage area $=98.4$; site 3 drainage area $=89.7$; site 4 drainage area $=9.38$, and site 5 drainage area $=3.26$. Load and average load are in bold. Standard error of prediction, in percent, is in (). Percentage of load carried in base-flow discharge is in italics, could be subject to some error because separate regression equations were utilized to estimate total load and baseflow load. No data available is -]

\begin{tabular}{|c|c|c|c|c|c|}
\hline \multirow{3}{*}{$\begin{array}{l}\text { Water } \\
\text { year }\end{array}$} & \multicolumn{5}{|c|}{ Annual loads } \\
\hline & \multicolumn{5}{|c|}{ Site name [site no. (fig. 1)] } \\
\hline & $\begin{array}{l}\text { Patuxent River } \\
\text { near Unity (1) }\end{array}$ & $\begin{array}{l}\text { Little Patuxent } \\
\text { River at Savage (2) }\end{array}$ & $\begin{array}{l}\text { Western Branch at } \\
\text { Upper Marlboro (3) }\end{array}$ & $\begin{array}{l}\text { Hunting Creek near } \\
\text { Huntingtown (4) }\end{array}$ & $\begin{array}{l}\text { Killpeck Creek at } \\
\text { Huntersville (5) }\end{array}$ \\
\hline 1986 & $0.13(5) 66$ & $0.29(7) 54$ & 0.15 (1) 38 & - & 0.02 (1) 54 \\
\hline 1987 & 0.20 (4) 55 & $0.43(7) 49$ & $0.22(0) 38$ & - & $0.02(5) 56$ \\
\hline 1988 & 0.25 (4) 68 & $\mathbf{0 . 4 5}(4) 56$ & $0.21(0) 35$ & - & $0.01(5) 63$ \\
\hline 1989 & $0.24(3) 69$ & $0.71(4) 49$ & - & $0.02(1) 49$ & $0.02(5) 59$ \\
\hline 1990 & $0.20(3) 76$ & $0.56(4) 64$ & - & 0.02 (1) 46 & $0.02(5) 60$ \\
\hline 1991 & $0.21(4) 70$ & $0.47(4) 61$ & - & $0.01(4) 60$ & $0.01(4) 67$ \\
\hline 1992 & $0.12(3) 71$ & $\mathbf{0 . 3 7}(3) 57$ & - & 0.01 (3) 44 & 0.01 (7) 50 \\
\hline 1993 & 0.34 (3) 65 & $0.76(4) 50$ & $0.28(7) 39$ & $0.01(7) 60$ & $0.02(5) 60$ \\
\hline 1994 & $0.32(3) 64$ & $\mathbf{0 . 8 5}(5) 43$ & $0.40(5) 27$ & $0.02(4) 52$ & $0.02(5) 54$ \\
\hline 1995 & $0.14(4) 78$ & $\mathbf{0 . 3 6}(3) 53$ & $0.15(7) 29$ & $0.01(2) 57$ & $0.01(6) 65$ \\
\hline 1996 & $\mathbf{0 . 3 9}(4) 59$ & $1.02(5) 37$ & $0.40(8) 26$ & $0.01(6) 53$ & $\mathbf{0 . 0 3}(7) 51$ \\
\hline $\begin{array}{l}\text { Average load, } \\
1993-96\end{array}$ & 0.3067 & 0.7546 & 0.3130 & 0.0156 & 0.0258 \\
\hline $\begin{array}{l}\text { Average yield, } \\
1993-96^{\text {a }}\end{array}$ & 0.0086 & 0.00761 & 0.0034 & 0.0011 & 0.0061 \\
\hline
\end{tabular}

a Average yield for a site is derived by dividing the average load from 1993-96, by the site's drainage area. 
Table 5. Estimated loads and yield of nitrite plus nitrate at five monitoring sites in the Patuxent River Basin, 1986-96

[Load is in millions of pounds. Average yield is in millions of pounds per year per square mile. Average load and yield are calculated for years when all sites have data. Drainage area is in square miles taken from table 1 - site 1 drainage area $=34.8$; site 2 drainage area $=98.4$; site 3 drainage area $=89.7$; site 4 drainage area $=9.38$, and site 5 drainage area $=3.26$. Load and average load are in bold. Standard error of prediction, in percent, is in ( ). Percentage of load carried in base-flow discharge is in italics, could be subject to some error because separate regression equations were utilized to estimate total load and baseflow load. No data available is -]

\begin{tabular}{|c|c|c|c|c|c|}
\hline \multirow{3}{*}{$\begin{array}{l}\text { Water } \\
\text { year }\end{array}$} & \multicolumn{5}{|c|}{ Annual loads } \\
\hline & \multicolumn{5}{|c|}{ Site name [site no. (fig. 1)] } \\
\hline & $\begin{array}{l}\text { Patuxent River } \\
\text { near Unity (1) }\end{array}$ & $\begin{array}{l}\text { Little Patuxent } \\
\text { River at Savage (2) }\end{array}$ & $\begin{array}{l}\text { Western Branch at } \\
\text { Upper Marlboro (3) }\end{array}$ & $\begin{array}{l}\text { Hunting Creek near } \\
\text { Huntingtown (4) }\end{array}$ & $\begin{array}{l}\text { Killpeck Creek at } \\
\text { Huntersville (5) }\end{array}$ \\
\hline 1986 & $0.09(4) 78$ & 0.18 (11) 71 & $0.05(10) 50$ & - & $0.007(11) 92$ \\
\hline 1987 & $0.14(4) 69$ & $0.23(9) 73$ & 0.07 (7) 54 & - & $\mathbf{0 . 0 7}$ (1) 95 \\
\hline 1988 & $0.18(3) 83$ & $0.26(4) 80$ & 0.07 (7) 49 & - & $0.005(6) 88$ \\
\hline 1989 & 0.17 (3) 84 & $0.34(3) 83$ & - & $0.004(15) 44$ & $0.008(50) 99$ \\
\hline 1990 & 0.16 (3) 87 & 0.33 (3) 93 & - & $0.005(10) 49$ & $0.009(4) 104$ \\
\hline 1991 & $0.16(3) 81$ & 0.29 (3) 84 & - & $0.002(10) 68$ & $0.006(5) 91$ \\
\hline 1992 & $0.10(3) 75$ & $0.25(4) 74$ & - & $0.001(20) 58$ & $0.006(5) 82$ \\
\hline 1993 & $0.25(3) 79$ & $0.42(2) 75$ & $0.10(7) 68$ & $0.004(10) 65$ & $0.009(6) 107$ \\
\hline 1994 & $0.24(3) 77$ & $0.43(5) 70$ & $\mathbf{0 . 1 3}(8) 55$ & $0.004(13) 56$ & $0.009(6) 106$ \\
\hline 1995 & $0.12(3) 83$ & $0.26(4) 67$ & $0.06(8) 46$ & $0.001(10) 66$ & $0.007(7) 93$ \\
\hline 1996 & $0.28(4) 75$ & $0.50(4) 66$ & $\mathbf{0 . 1 4}(8) 56$ & $0.002(15) 56$ & $0.011(9) 106$ \\
\hline $\begin{array}{l}\text { Average load, } \\
1993-96\end{array}$ & 0.2279 & 0.4076 & 0.1156 & 0.00361 & 0.009103 \\
\hline $\begin{array}{l}\text { Average yield, } \\
1993-96^{\mathrm{a}}\end{array}$ & 0.0064 & 0.0041 & 0.0012 & 0.0003 & 0.0028 \\
\hline
\end{tabular}

\footnotetext{
${ }^{\text {a }}$ Average yield for a site is derived by dividing the average load from 1993-96, by the site's drainage area.
} 
Table 6. Estimated loads and yield of total phosphorus at five monitoring sites in the Patuxent River Basin, 1986-96

[Load is in millions of pounds. Average yield is in millions of pounds per year per square mile. Average load and yield are calculated for years when all sites have data. Drainage area is in square miles taken from table 1 - site 1 drainage area $=34.8$; site 2 drainage area $=98.4$; site 3 drainage area $=89.7$; site 4 drainage area $=9.38$, and site 5 drainage area $=3.26$. Load and average load are in bold. Standard error of prediction, in percent, is in ( ). Percentage of load carried in base-flow discharge is in italics, could be subject to some error because separate regression equations were utilized to estimate total load and baseflow load. No data available is -]

\begin{tabular}{|c|c|c|c|c|c|}
\hline \multirow{3}{*}{$\begin{array}{l}\text { Water } \\
\text { year }\end{array}$} & \multicolumn{5}{|c|}{ Annual loads } \\
\hline & \multicolumn{5}{|c|}{ Site name [site no. (refer to fig. 1)] } \\
\hline & $\begin{array}{l}\text { Patuxent River } \\
\text { near Unity (1) }\end{array}$ & $\begin{array}{l}\text { Little Patuxent } \\
\text { River at Savage (2) }\end{array}$ & $\begin{array}{l}\text { Western Branch at } \\
\text { Upper Marlboro (3) }\end{array}$ & $\begin{array}{l}\text { Hunting Creek near } \\
\text { Huntingtown (4) }\end{array}$ & $\begin{array}{l}\text { Killpeck Creek at } \\
\text { Huntersville (5) }\end{array}$ \\
\hline 1986 & $0.006(17) 35$ & $0.029(38) 11$ & 0.029 (21) 18 & - & $0.003(33) 17$ \\
\hline 1987 & $0.021(33) 13$ & $0.083(37) 6$ & $0.041(17) 17$ & - & $0.003(33) 19$ \\
\hline 1988 & $0.021(29) 19$ & $0.067(30) 9$ & $0.043(16) 14$ & - & $0.001(30) 25$ \\
\hline 1989 & $0.029(69) 13$ & $0.238(47) 5$ & - & 0.007 (14) 30 & $0.004(18) 18$ \\
\hline 1990 & $0.008(13) 31$ & $0.078(29) I 1$ & - & 0.006 (17) 29 & $0.005(20) 16$ \\
\hline 1991 & $0.017(76) 11$ & $0.056(36) 9$ & - & $0.001(20) 48$ & $0.001(70) 26$ \\
\hline 1992 & $0.003(33) 28$ & $0.031(32) 8$ & - & $0.001(20) 38$ & $0.002(50) 11$ \\
\hline 1993 & $0.016(25) 19$ & $0.107(35) 7$ & $0.059(19) 12$ & $0.002(10) 46$ & $0.003(3) 14$ \\
\hline 1994 & $0.016(50) 13$ & $0.194(65) 3$ & $0.122(21) 6$ & $0.003(13) 37$ & $0.004(15) 11$ \\
\hline 1995 & $0.002(25) 35$ & $0.018(28) 7$ & $0.029(24) 11$ & $0.001(10) 47$ & $0.001(100) 27$ \\
\hline 1996 & $0.027(41) 7$ & $0.220(40) 2$ & $0.104(18) 7$ & $0.002(15) 34$ & $0.004(25) 11$ \\
\hline $\begin{array}{l}\text { Average load, } \\
1993-96\end{array}$ & 0.01519 & 0.1355 & 0.0789 & 0.00241 & 0.00316 \\
\hline $\begin{array}{l}\text { Average yield, } \\
1993-96^{\text {a }}\end{array}$ & 0.00044 & 0.00137 & 0.00088 & 0.00021 & 0.00092 \\
\hline
\end{tabular}

a Average yield for a site is derived by dividing the average load from 1993-96, by the site's drainage area. 
Table 7. Estimated loads and yield of total suspended solids at five monitoring sites in the Patuxent River Basin, 1986-96

[Load is in millions of pounds. Average yield is in millions of pounds per year per square mile. Average load and yield are calculated for years when all sites have data. Drainage area is in square miles taken from table 1 - site 1 drainage area $=34.8$; site 2 drainage area $=98.4$; site 3 drainage area $=89.7$; site 4 drainage area $=9.38$, and site 5 drainage area $=3.26$. Load and average load are in bold. Standard error of prediction, in percent, is in ( ). Percentage of load carried in base-flow discharge is in italics, could be subject to some error because separate regression equations were utilized to estimate total load and baseflow load. No data is -]

\begin{tabular}{|c|c|c|c|c|c|}
\hline \multirow{3}{*}{$\begin{array}{l}\text { Water } \\
\text { year }\end{array}$} & \multicolumn{5}{|c|}{ Annual loads } \\
\hline & \multicolumn{5}{|c|}{ Site name [site no. (refer to fig. 1)] } \\
\hline & $\begin{array}{l}\text { Patuxent River } \\
\text { near Unity (1) }\end{array}$ & $\begin{array}{l}\text { Little Patuxent } \\
\text { River at Savage (2) }\end{array}$ & $\begin{array}{l}\text { Western Branch at } \\
\text { Upper Marlboro (3) }\end{array}$ & $\begin{array}{l}\text { Hunting Creek near } \\
\text { Huntingtown (4) }\end{array}$ & $\begin{array}{l}\text { Killpeck Creek at } \\
\text { Huntersville (5) }\end{array}$ \\
\hline 1986 & $0.8(50) 19$ & $2.0(80) 6$ & $5.2(50) 8$ & - & $0.3(67) 14$ \\
\hline 1987 & $5.2(85) 4$ & $18.6(91) 1$ & $8.1(33) 8$ & - & $0.4(75) 14$ \\
\hline 1988 & $6.6(70) 5$ & $19.8(65) 2$ & $9.7(35) 5$ & - & $0.2(100) 13$ \\
\hline 1989 & $16.7(182) 2$ & $159.3(99) l$ & - & $0.7(29) 15$ & $1.6(56) 5$ \\
\hline 1990 & $2.4(42) 15$ & $53.2(70) 2$ & - & $0.8(25) 16$ & $3.2(109) 3$ \\
\hline 1991 & $8.3(177) 4$ & $48.8(86) \quad l$ & - & $0.2(20) 32$ & $0.3(67) 9$ \\
\hline 1992 & $1.5(80) 17$ & $33.2(86) l$ & - & $0.2(20) 24$ & $2.0(110) 1$ \\
\hline 1993 & 10.9 (52) 7 & $135.9(80) 2$ & $23.2(47) 6$ & 0.5 (14) 34 & $3.4(126) 3$ \\
\hline 1994 & 13.6 (109) 5 & $301.6(142)$ l & 74.7 (47) 2 & $0.6(25) 25$ & $3.9(92) 3$ \\
\hline 1995 & $1.3(62) 27$ & $17.5(70) 2$ & 12.5 (62) 3 & $0.2(15) 31$ & $0.2(35) 14$ \\
\hline 1996 & 35.6 (97) 2 & 342.1 (87) l & $58.8(41) 3$ & $0.4(23) 21$ & $2.5(96) 3$ \\
\hline $\begin{array}{l}\text { Average load, } \\
1993-96\end{array}$ & 15.410 & 199.32 & 42.34 & 0.428 & 2.66 \\
\hline $\begin{array}{l}\text { Average yield, } \\
1993-96^{\mathrm{a}}\end{array}$ & 0.25 & 1.54 & 0.41 & 0.01 & 0.77 \\
\hline
\end{tabular}

a Average yield for a site is derived by dividing the average load from 1993-96, by the site's drainage area. 
Table 8. Estimated loads and yield of suspended sediment at five monitoring sites in the Patuxent River Basin, 1986-96

[Load is in millions of pounds. Average yield is in millions of pounds per year per square mile. Average load and yield are calculated for years when all sites have data. Drainage area is in square miles taken from table 1 -site 1 drainage area $=34.8$; site 2 drainage area $=98.4$; site 3 drainage area $=89.7$; site 4 drainage area $=9.38$, and site 5 drainage area $=3.26$; load and average load are in bold. Standard error of prediction, in percent, is in ( ). Percentage of load carried in base-flow discharge is in italics, could be subject to some error because separate regression equations were utilized to estimate total load and baseflow load. No data is -]

\begin{tabular}{|c|c|c|c|c|c|}
\hline \multirow{3}{*}{$\begin{array}{l}\text { Water } \\
\text { year }\end{array}$} & \multicolumn{5}{|c|}{ Annual loads } \\
\hline & \multicolumn{5}{|c|}{ Site name [site no. (refer to fig. 1] } \\
\hline & $\begin{array}{l}\text { Patuxent River } \\
\text { near Unity (1) }\end{array}$ & $\begin{array}{l}\text { Little Patuxent } \\
\text { River at Savage (2) }\end{array}$ & $\begin{array}{l}\text { Western Branch at } \\
\text { Upper Marlboro (3) }\end{array}$ & $\begin{array}{l}\text { Hunting Creek near } \\
\text { Huntingtown (4) }\end{array}$ & $\begin{array}{l}\text { Killpeck Creek at } \\
\text { Huntersville (5) }\end{array}$ \\
\hline 1986 & $2.9(66) 13$ & $16.6(58) 5$ & $\mathbf{1 5 . 6}(42) 10$ & - & $0.8(75) 21$ \\
\hline 1987 & $17.0(125) 4$ & $69.7(62) 1$ & $25.4(32) 8$ & - & $1.2(50) 17$ \\
\hline 1988 & $15.7(94) 7$ & $50.3(50) 2$ & 27.0 (31) 5 & - & $0.5(80) 14$ \\
\hline 1989 & 20.5 (197) 6 & $282.7(83) 1$ & - & $0.9(33) 23$ & $3.7(51) 7$ \\
\hline 1990 & $5.7(70) 12$ & $61.7(52) 2$ & - & $1.1(27) 17$ & $6.0(93) 4$ \\
\hline 1991 & $16.8(268) 3$ & $50.3(63) \quad 1$ & - & $0.2(20) 27$ & $0.6(50) 8$ \\
\hline 1992 & $2.9(148) 11$ & $22.6(58) 1$ & - & $0.3(17) 20$ & 2.9 (97) 1 \\
\hline 1993 & 13.5 (72) 7 & $114.2(64) l$ & $42.7(30) 4$ & $0.6(15) 23$ & $4.4(102) 3$ \\
\hline 1994 & $16.8(157) 4$ & $314.6(109) 0$ & $84.2(33) 2$ & $0.9(23) 17$ & $5.0(78) 2$ \\
\hline 1995 & $1.8(83) 13$ & $12.5(48) 2$ & $18.9(42) 3$ & $0.2(15) 29$ & $0.3(33) 7$ \\
\hline 1996 & $47.3(128) 1$ & $\mathbf{3 4 7 . 0}(67) 0$ & $71.1(29) 3$ & $0.5(20) 23$ & 3.3 (88) 2 \\
\hline $\begin{array}{l}\text { Average load, } \\
1993-96\end{array}$ & 19.96 & 197.11 & 54.23 & 0.623 & 3.34 \\
\hline $\begin{array}{l}\text { Average yield, } \\
1993-96^{\mathrm{a}}\end{array}$ & 0.57 & 2.00 & 0.60 & 0.06 & 1.00 \\
\hline
\end{tabular}

a Average yield for a site is derived by dividing the average load from 1993-96, by the site's drainage area. 


\section{Comparison of Yields Among Subwatersheds}

In order to make meaningful comparisons of the estimated loads at the five subwatersheds, yields were calculated. Yields are annual loads that are normalized by the area of the respective subwatershed (yield equals the annual load divided by the area of the subwatershed). The area of the subwatershed is a major factor in determining the amount of rainfall that is captured within the subwatershed, and thus the amount of ground-water discharge and surface runoff and, consequently, streamflow. As a result, differences in annual load among subwatersheds can be due in part to subwatershed area. Remaining interbasin differences in loading rates could be attributable to differences in rainfall volume or to basin characteristics that affect constituent loading, such as geology or land-use practices.

To determine whether there are significant differences in rainfall and response to rainfall among the sites that could produce differences in yields, annual water yield is presented in units of depth (inches) to indicate the amount of rainfall that is converted to discharge. Water yield is affected by many factors, but is usually higher at sites that have received more rainfall, have a higher percentage of impervious area, or have shorter flow paths. Preston and Summers (1996) reported that among the monitored subwatersheds, differences in annual water yield appear to be due primarily to differences in the amount of rainfall received, rather than to differences in basin characteristics. For 1986-96, water yield was fairly similar among sites (fig. 7), especially during the later years of the study, 1993-96.

The highest yields of nitrite plus nitrate were from the Patuxent River near Unity and Little Patuxent River at Savage subwatersheds (fig. 8).
This is consistent with other research that showed concentrations of nitrate to be higher in the Piedmont than in the Coastal Plain during baseflow conditions in the Patuxent River Basin (Preston, 1996). Reasons for higher yields at the northern sites also could be related to land use/ land cover; there is more developed agricultural and urban land in the northern Piedmont part of the Patuxent River Basin. Land cover in the Coastal Plain part of the Patuxent River Basin is predominantly forested.

Yields of total nitrogen are also higher from the Piedmont subwatersheds. In the Killpeck Creek at Huntersville subwatershed, however, total nitrogen yields were high when the water yield was high. The other Coastal Plain subwatersheds did not show as pronounced a response to highstreamflow years. Further investigation is needed to determine the reasons for these differences within the Coastal Plain.

Consistent differences in total phosphorus, total suspended solids, and suspended-sediment yields were apparent among the monitored subwatersheds. The Little Patuxent River at Savage, Western Branch at Upper Marlboro, and Killpeck Creek at Huntersville subwatersheds had the highest and the most variable total phosphorus yields. These subwatersheds are among the most urbanized in the river basin. Total suspended solids and suspended-sediment yields were highest at the Little Patuxent River at Savage subwatershed. The Patuxent River near Unity subwatershed had some of the highest yields of nitrogen, but phosphorus and sediment yields were comparatively low. The predominantly forested Hunting Creek near Huntingtown subwatershed had the lowest yields for all five water-quality constituents. 

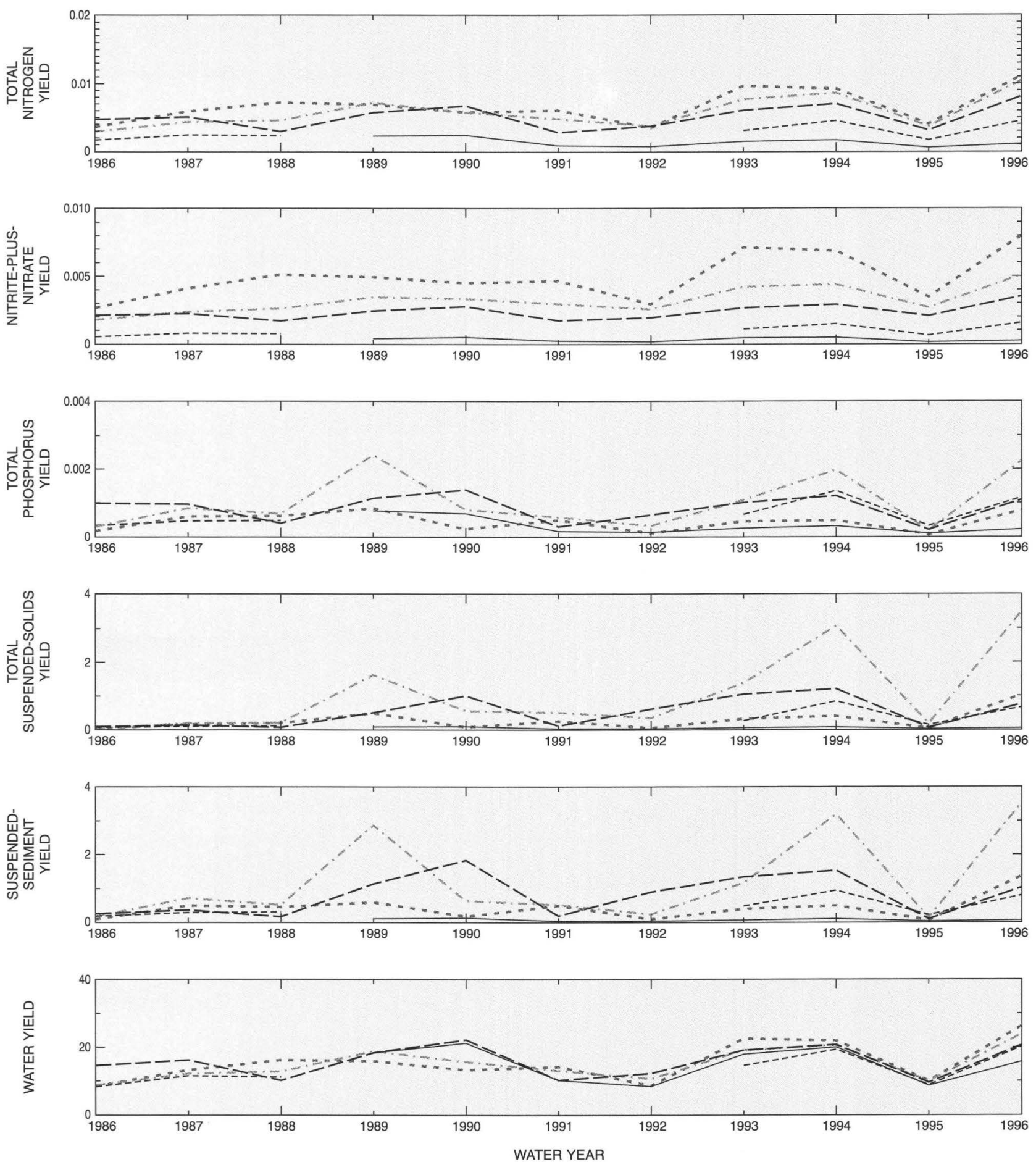

\section{EXPLANATION}

. . . . . PATUXENT RIVER NEAR UNITY

-... - LITTLE PATUXENT RIVER AT SAVAGE

- - KILLPECK CREEK AT HUNTERSVILLE

----.- WESTERN BRANCH AT UPPER MARLBORO

HUNTING CREEK NEAR HUNTINGTOWN

Figure 7. Annual yields of nutrients, suspended solids, suspended sediment, and water from five subwatersheds in the Patuxent River Basin, 1986-96. [Nutrients, suspended solids, and suspended sediment are in millions of pounds per square mile; water yields are in inches.] 

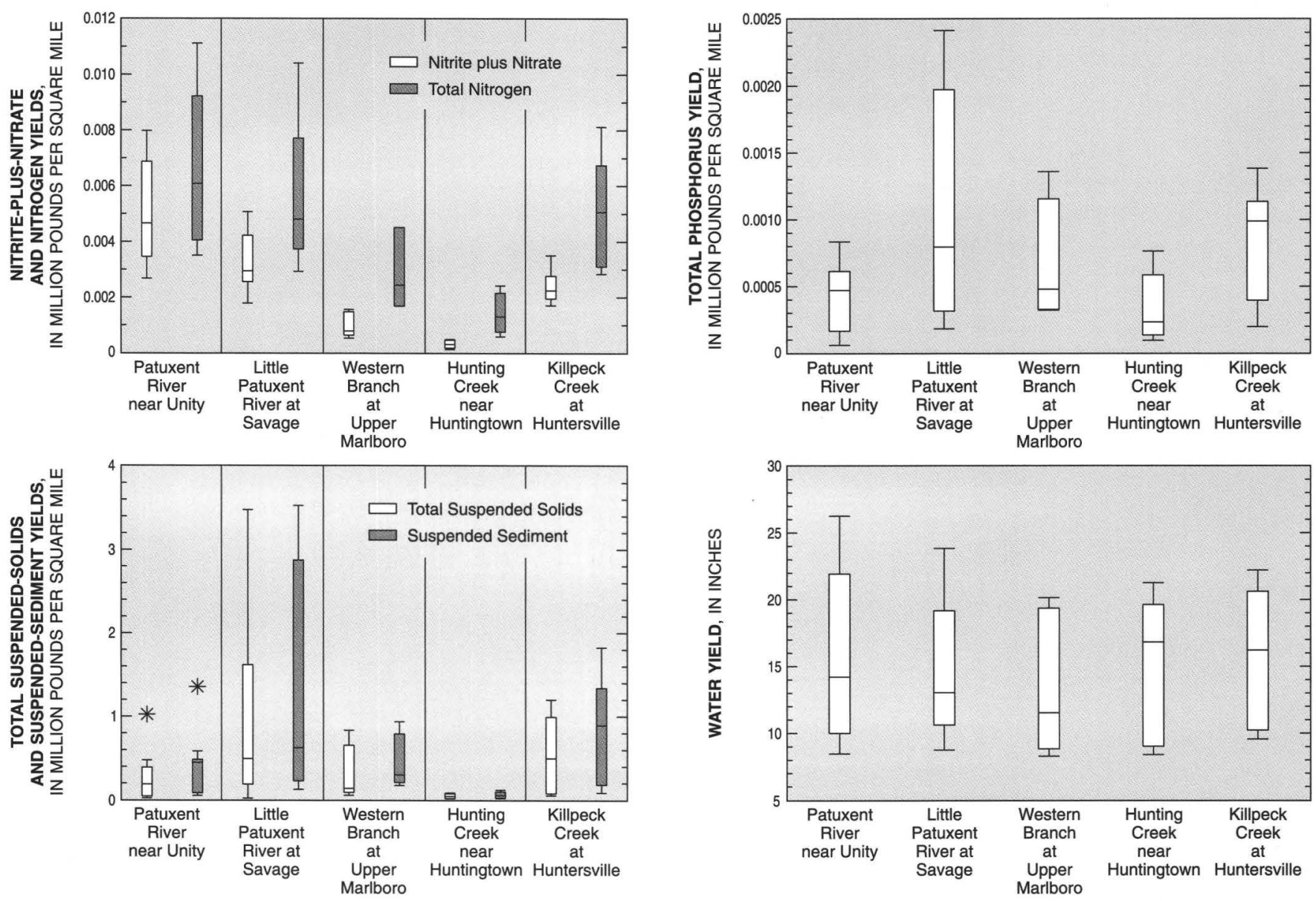

\section{EXPLANATION}

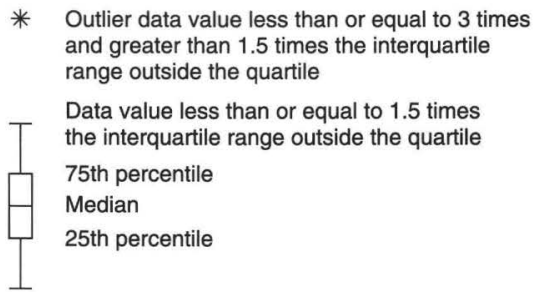

Figure 8. Distribution of annual yields of nutrients, suspended solids, suspended sediment, and water from five subwatersheds in the Patuxent River Basin, 1986-96. [Boxplots for Western Branch do not include yields from 1989-92; boxplots for Hunting Creek do not include yields from 1986-88.] 


\section{Summary}

The Patuxent River Basin was intensively sampled from 1986-96 to assess progress toward Chesapeake Bay Program nutrient- and sedimentreduction goals for the year 2000. Five representative subwatersheds were sampled to estimate nutrient and sediment concentrations, trends, loads, and yields with time. The nutrient loading in these subwatersheds is dominated by nonpoint sources, with point-source loading being insignificant. These subwatersheds represent approximately 25 percent of the surface area of the basin.

On the basis of data collected from 1993-96, when all five sites were in operation, the estimated average-annual total nitrogen load from these subwatersheds was 1.4 million pounds, and the estimated average-annual load of nitrite plus nitrate was 0.74 million pounds, slightly more than half of the load of total nitrogen. The estimated average-annual load of total phosphorus was 0.23 million pounds. The estimated averageannual loads of suspended solids and suspended sediment were 260 and 275 million pounds, respectively. These amounts are equivalent to 40 percent of the 3.5-million-pound goal for combined point- and nonpoint-source nitrogen load and 70 percent of the 0.33 -million-pound goal for point- and- nonpoint-source phosphorus load for the Patuxent River Basin.

There was no significant decrease in concentrations of total nitrogen or nitrite plus nitrate from 1986-96 at most of these sites. Concentrations of total nitrogen significantly increased at the sites located at the outlets of the most rapidly developing subwatersheds. Concentrations of total phosphorus decreased at all the sites, and this decrease appears to have occurred independently of sediment control. The decrease in concentrations of total phosphorus may be due in part to the phosphate-detergent ban in the late 1980's.

Differences in yield among these subwatersheds appear to be related to a combination of the hydrologic and waterchemistry characteristics of physiographic provinces and land uses. Nitrite-plus-nitrate yields were lower from the southern Coastal Plain subwatersheds of Western Branch at Upper Marlboro, Hunting Creek near Huntingtown, and Killpeck Creek at Huntersville, than from the northern Piedmont subwatersheds of the Patuxent River near Unity and the Little Patuxent River at Savage. Further evaluation is needed to identify reasons for the differences with more certainty and to explain why total nitrogen yields at the Killpeck Creek site are higher than at the other two Coastal Plain sites.

Annual yields of total phosphorus, total suspended solids, and suspended sediment decreased and increased in concert with decreasing and increasing annual water yields from each subwatershed. The subwatersheds of the Little Patuxent River at Savage, Western Branch at Upper Marlboro, and Killpeck Creek at Huntersville, the most urbanized of the monitored subwatersheds in the Patuxent River Basin, showed some of the highest and most variable yields of these three water-quality constituents. 


\section{References Cited}

American Public Health Association, 1975, Standard Methods for the Examination of Water and Wastewater, 14th ed., New York, 1,193 p.

Bradu, Dan, and Mundlak, Yair, 1970, Estimation in lognormal linear models: Journal of the American Statistical Association, v. 65, no. 329 , p. 198-211.

Buchanan, T.J., and Somers, W.P., 1982, Stage measurement at gaging stations: U.S. Geological Survey Techniques of WaterResources Investigations, book 3, chap. A7, $28 \mathrm{p}$.

Carter, R.W., and Davidian, J., 1968, General procedure for gaging streams: U.S. Geological Survey Techniques of Water-Resources Investigations, book 3, chap. A6, 13 p.

Cohn, T.A., 1988, Adjusted maximum likelihood estimation of the moments of log normal populations from Type I censored samples: U.S. Geological Survey Open-File Report 88-350, 34 p.

Cohn, T.A., DeLong, L.L., Gilroy, E.J., Hirsch, R.M., and Wells, D.K., 1989, Estimating constituent loads: Water Resources Research, 25 (5), p. 937-942.

Cohn, T.A., Caulder, D.L., Gilroy, E.J., Zynjuk, L.D., and Summers, R.M., 1992, The validity of a simple log-linear model for estimating fluvial constituent loads: An empirical study involving nutrient loads entering Chesapeake Bay: Water Resources Research, v. 28, no. 9, p. 2,353-2,364.

Cohn, T.A., 1995, Recent advances in statistical methods for the estimation of sediment and nutrient transport in rivers: Chapter 21 in Contributions in Hydrology, U.S. National Report to the International Union of Geodesy and Geophysics, pp. 1,117-1,124.

Darrell, L.C., Feit Majedi, B.L., Lizárraga, J.S., and Blomquist, J.D., in press, Nutrient and suspended-sediment concentrations, trends, loads, and yields in the nontidal part of the Susquehanna, Potomac, Patuxent, and Choptank Rivers, 1985-96: U.S. Geological Survey Water-Resources Investigations Report 98-4177.
Fishman, M.J., and Friedman, L.C., 1989, Methods for determination of inorganic substances in water and fluvial sediments: U.S. Geological Survey Techniques of WaterResources Investigations, book 5, chap. A1, $545 \mathrm{p}$.

Galloway, Bruce, ed., 1993, A work in progress: A retrospective on the first decade of the Chesapeake Bay restoration: Chesapeake Bay Program, Annapolis, Md., 44 p.

Guy, H.P., 1969, Laboratory theory and methods for sediment analysis: U.S. Geological Survey Techniques of Water-Resources Investigations, book 5, chap. C1, 58 p.

Guy, H.P., and Norman, V.W., 1970, Field methods for measurement of fluvial sediments: U.S. Geological Survey Techniques of WaterResources Investigations, book 3, chap. C2, $59 \mathrm{p}$.

Heinle, D.R., Taft, J.L., D'Elia, C.F., Wilson, J.S., Cole-Jones, M., and Vivian, A.B., 1980,

Historical review of water quality and climatic data from Chesapeake Bay with emphasis on effects of enrichment: Solomons, Md., Chesapeake Research Consortium, Inc., Publication No. 84.

Kennedy, E.J., 1983, Computations of continuous records of streamflow: U.S. Geological Survey Techniques of Water-Resources Investigations, book 3, chap. A13, 53 p.

Koterba, M.T., Dysart, J.E., Phillips, S.W., and Zynjuk, L.D., 1994, Use and value of qualitycontrol data in studies in the Chesapeake Bay region, in Pederson, G.L., ed., National Symposium on Water Quality, Herndon, Va., American Water Resources Association, p. 65-74.

Langland, M.J., Edwards, R.E., and Darrell, L.C., 1998, Status yields and trends of nutrients and sediment and methods of analysis for the nontidal data-collection programs, Chesapeake Bay Basin, 1985-96: U.S. Geological Survey Open-File Report 98-17, 60 p. 
Langland, M.J., Lietman, P. L., and Hoffman, Scott, 1995, Synthesis of nutrient and sediment data for watersheds within the Chesapeake Bay drainage basin: U.S. Geological Survey Water-Resources Investigations Report 95-4233, $121 \mathrm{p}$.

McFarland, E.R, 1996, Ground-water flow, geochemistry, and effects of agricultural practices on nitrogen transport at study sites in the Piedmont and Coastal Plain Physiographic Provinces, Patuxent River Basin, Maryland: U.S. Geological Survey Water-Supply Paper 2449, $72 \mathrm{p}$.

Mihursky, J.L., and Boynton, W.R., 1978, Review of Patuxent estuary data base--Report submitted to Maryland Department of Natural Resources Power Plant Siting Program: Contract No. 2-72-02 (78).

O'Conner, D.J., Gallagher, T.W., and Hallden, J.A., 1981, Water quality analysis of the Patuxent River--Report to the U.S. Environmental Protection Agency and Maryland Department of Health and Mental Hygiene: Amhara, N.J., Hydroqual, Inc., 238 p.

Office of Environmental Programs, 1983, 208 Water quality management plan for the Patuxent River basin: Baltimore, Md., Maryland Department of Health and Mental Hygiene.

Patuxent River Commission, 1996, Patuxent River Tributary Team, Annual Report, 1995-1996, $24 \mathrm{p}$.

Preston, S.D., 1996, Study of nonpoint source nutrient loading in the Patuxent River Basin, Maryland: U.S. Geological Survey WaterResources Investigations Report 96-4273, 6 p.
Preston, S.D., and Summers, R. M., 1996, Estimation of nutrient and suspended-sediment loads in the Patuxent River Basin, Maryland, water years 1986-90: U.S. Geological Survey Water-Resources Investigations Report 96-4175, 69 p.

Sloto, R.A., and Crouse, M.Y., 1996, HYSEP: A computer program for streamflow hydrograph separation and analysis: U.S. Geological Survey Water-Resources Investigations Report 96-4040, 46 p.

U.S. Environmental Protection Agency, 1979, Methods for chemical analysis of water and wastes: Washington, D.C., U.S. Government Printing Office, p. 353.2-1. 1988, Chesapeake Bay Agreement, in Comprehensive research plan, an agreement commitment report from the Chesapeake Executive Council [variously paged]. 1990, A report to Congress on the Patuxent River: Annapolis, Md., U.S. Environmental Protection Agency, Chesapeake Bay Program Office. 1992, Progress report of the baywide nutrient reduction evaluation: February 1992, Chesapeake Bay Program Office.

Voinov, Alexey, Integrated ecological economic modeling and valuation of watersheds, Patuxent River Basin, University of Maryland, Solomons Island, Md., accessed April 20, 1998, on world wide web at url http://kabir.cbl.umces.edu/PLM. 